Chemical Technology Division

\title{
EVAPORATION STUDIES ON OAK RIDGE NATIONAL LABORATORY LIQUID LOW-LEVEL WASTE
}

\author{
V. L. Fowler* \\ J. J. Perona
}

"PAI Corporation, 116 Milan Way, Oak Ridge, Tennessee 37831

Date Published: March 1993

NOTICE This document contains information of a preliminary nature. It is subject to revision or correction and therefore does not represent a final report.

\author{
Prepared by \\ OAK RIDGE NATIONAL LABORATORY \\ Oak Ridge, Tennessee 37831-6285 \\ managed by \\ MARTIN MARIETTA ENERGY SYSTEMS, INC. \\ for the \\ U.S. DEPARTMENT OF ENERGY \\ under contract DE-AC05-84OR21400
}


TABLE OF CONTENTS

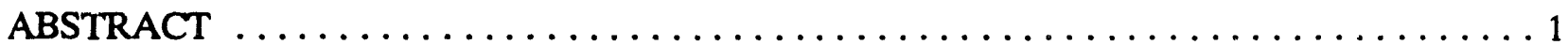

1. INTRODUCTION $\ldots \ldots \ldots \ldots \ldots \ldots \ldots \ldots \ldots \ldots \ldots \ldots \ldots \ldots \ldots \ldots \ldots$

2. PRELIMINARY VOLUME REDUCTION STUDIES $\ldots \ldots \ldots \ldots \ldots \ldots \ldots \ldots \ldots$

2.1 VOLUME REDUCTION BY BOILING AT ATMOSPHERIC PRESSURE . . . 3

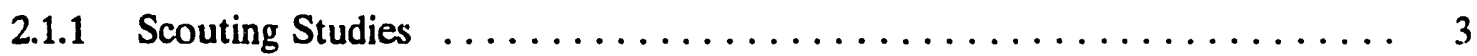

2.1.2 Additional Studies $\ldots \ldots \ldots \ldots \ldots \ldots \ldots \ldots \ldots \ldots \ldots \ldots \ldots \ldots$

2.2 VOLUME REDUCTION BY AIR SPARGING AT AMBIENT

TEMPERATURE AND PRESSURE $\ldots \ldots \ldots \ldots \ldots \ldots \ldots \ldots \ldots \ldots$

2.3 VOLUME REDUCTION BY BOILING AT SUBATMOSPHERIC

PRESSURES AND LOW TEMPERATURES $\ldots \ldots \ldots \ldots \ldots \ldots \ldots \ldots \ldots \ldots$

3. PROJECTED LIQUID LOW-LEVEL WASTE VOLUME REDUCTIONS BY

THE OUT-OF-TANK EVAPORATION PROCESS $\ldots \ldots \ldots \ldots \ldots \ldots \ldots \ldots$

3.1 OPERATIONAL TIME REQUIREMENTS $\ldots \ldots \ldots \ldots \ldots \ldots \ldots \ldots$

4. SUMMARY AND RECOMMENDATIONS $\ldots \ldots \ldots \ldots \ldots \ldots \ldots \ldots \ldots \ldots$

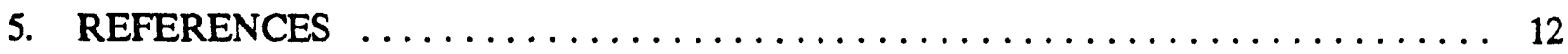

Appendix. FINAL REPORT SURROGATE SOLUTION TEST,

OAK RIDGE NATIONAL LABORATORY, LICON, INC . . . . . . . . . . . 13 


\title{
EVAPORATION STUDIES ON OAK RIDGE NATIONAL LABORATORY LIQUID LOW-LEVEL WASTE
}

\author{
V. L. Fowler \\ J. J. Perona
}

\begin{abstract}
Evaporation studies were performed with Melton Valley storage tank liquid low-level radioactive waste concentrate and with surrogates (nonradioactive) to determine the feasibility of a proposed out-of-tank-evaporation project. Bench-scale tests indicated that volume reductions ranging from 30 to $55 \%$ could be attained. Vendor-site tests were conducted (with surrogate waste forms) using a bench-scale single-stage, low-pressure (subatmospheric), lowtemperature $\left(120\right.$ to $\left.173^{\circ} \mathrm{F}\right)$ evaporator similar to units in operation at several nuclear facilities. Vendor tests were successful; a $30 \%$ volume reduction was attained with no crystallization of solids and no foaming, as would be expected from a high $\mathrm{pH}$ solution. No fouling of the heat exchanger surfaces occurred during these tests. It is projected that 52,000 to $120,000 \mathrm{gal}$ of water could be evaporated from the supernate stored in the Melton and Bethel Valley liquid low-level radioactive waste (LLLW) storage tanks with this type of evaporator.
\end{abstract}

\section{INTRODUCTION}

The evolving underground injection control regulations (Chap. 1200-4-6) of the rules of the Water Quality Board for the state of Tennessee (first issued May 22, 1985) have led to the discontinuation of the hydrofracture process, which was used at the Oak Ridge National Laboratory (ORNL) to dispose of concentrated LLLW from the mid-1960s until late 1984. Since late 1984 , LLLW concentrate generated at ORNL has been stored in the eight 50,000-gal Melton Valley storage tanks (MVSTs), identified as W-24 through W-31, and in four 50,000-gal Bethei Valley evaporator service tanks, identified as C-1, C-2, W-21, and W23. The operational safety requirement for these 12 tanks dictates that they be filled to no more than $95 \%$ of their capacity (and maintain at least 50,000 gal free volume), or 520,000 gal. $^{1}$ An operational flexibility limit (OFL) of 470,000 gal for the subject tanks has been established by Waste Management personnel. The LLLW data base indicates that as of 
January 1992, the 12 tanks contained a total inventory of 460,500 gal (sludge and supernate), which approaches the OFL. To avoid shutdown of the ORNL LLLW system before 1997, when new storage tanks will come on line, interim waste treatment options must be implemented. Interim treatment options include source reduction, supernate evaporation (intank and out-of-tank), and solidification in concrete. ${ }^{2}$ Since late $1988,-100,000$ gal has been solidified and an additional 50,000-gal solidification program is planned for FY 1993. Assuming a $50 \%$ volume increase during solidification, a final waste volume totaling 225,000 gal of Class L-IV waste will have been produced. Currently, there is no U.S. Department of Energy-approved disposal method for this class of waste.

Operation of the in-tank-evaporation process (sparging six MVSTs with dehumidified air) will evaporate an estimated 11,000 gal in 1992 and $1993^{23}$, and the planned solidification campaign $(50,000 \mathrm{gal})$ in FY 1993 will reduce the current inventory; however, according to current LLLW generation projections, including source reductions, the inventory will reach the OFL of $470,000 \mathrm{gal}$ in November 1994. To avoid reaching the OFL, an out-of-tank evaporation (OTE) process has been chosen as the waste treatment option to prevent the need for additional solidification campaigns. The OTE process will not result in production of any solid waste.

In support of the OTE process, evaporation studies have been performed using surrogate waste forms and actual MVST supernate. This report describes those activities.

\section{PREIIMINARY VOLUME REDUCTION STUDIES}

Bench-scale preliminary volume reduction studies were performed to determine the maximum volume reduction ratios that could be achieved before crystallization of the dissolved salts occurred, using a simulated and actual MVST supernate. The major component of the MVST supernate is sodium, approximately $4 \mathrm{~mol} / \mathrm{L}$. Other cations such 
as $\mathrm{Ca}, \mathrm{Mg}, \mathrm{K}, \mathrm{Al}$, and $\mathrm{Fe}$ are present in concentrations up to about $0.25 \underline{M}$. Nitrates are present in quantities of about $4 \mathrm{~mol} / \mathrm{L}$. The $\mathrm{pH}$ ranges from about 9 to $>13$. The supernate contains various beta and gamma-emitting radionuclides, primarily ${ }^{90} \mathrm{Sr}$ and ${ }^{137} \mathrm{Cs}$. The transuranic content of the liquid is generally less than $100 \mathrm{nCi} / \mathrm{mL}$. The actual composition of the stored LLLW has been well documented in other reports ${ }^{4,5}$ and will not be repeated in this report.

\section{VOLUME REDUCTION BY BOILING AT ATMOSPHERIC PRESSURE}

\subsubsection{Scouting Studies}

A 1.2-L aliquot of simulated supernate, formulation based upon the MVST W-29 composition as detailed in the Peretz report ${ }^{4}$, was evaporated in a boiling flask equipped with a heating mantle. The vapor was routed to a total condenser. Evaporation continued until crystals formed in the concentrate. At this point, the concentrate was cooled to ambient temperature $\left(73^{\circ} \mathrm{F}\right)$. Small aliquots of the distillate were then added back to the concentrate, with agitation, until the precipitated solids were dissolved. A volume reduction of $38 \%$ was determined (E. D. Collins, MMES, personal communication to V. L. Fowler, January 4 and $28,1988)$. The test was then repeated using a 1.2-L aliquot from an archive sample of W-29 supernate (acquired in November 1985). The test procedure followed : ras the same as described previously, and it was determined that a volume reduction of $38 \%$ was achieved (E. D. Collins, MMES, personal communication to V. L. Fowler, January 4 and 28, 1988). Analytical results of samples from the MVST W-29 test are presented in Table 1. 
Table 1. Melton Valley storage tank W-29 supernate volume reduction: component distribution

\begin{tabular}{lccc}
\hline \multicolumn{1}{c}{ Component } & Feed & Concentrate & Distillate \\
\hline Gross alpha, Bq/mL & $6.50 \mathrm{E}+0$ & $9.60 \mathrm{E}+0$ & $9.08 \mathrm{E}+0$ \\
Gross beta, $\mathrm{Bq} / \mathrm{mL}$ & $2.59 \mathrm{E}+5$ & $3.98 \mathrm{E}+5$ & $3.11 \mathrm{E}+2$ \\
Gross gamma, c/m/mL & $2.73 \mathrm{E}+6$ & $4.46 \mathrm{E}+6$ & $1.10 \mathrm{E}+4$ \\
$\mathrm{pH}$ & 13.0 & 13.3 & 9.4 \\
OH $^{-}, \underline{M}$ & 0.40 & 0.69 & 0.0006 \\
sp gr, g/cc & 1.2486 & 1.4137 & 0.9978 \\
Total solids, $\mathrm{mg} / \mathrm{mL}$ & 79.8 & 135.0 & N.R. \\
\hline
\end{tabular}

${ }^{a}$ N.R. = assay not requested.

The decontamination factors (DF) for gross beta and gamma, respectively, are 833 and 250 , but they are meaningless in that no liquid/vapor separator or demister was present in the system. The DF as calculated from the analytical data shown in Table 1 are

$$
\mathrm{DF}=\text { feed concentration/distillate concentration }
$$

The tests described indicated that MVST supernate volume reduction by elevatedtemperature evaporation was indeed a viable alternative to solidification. Therefore, benchscale tests were continued.

\subsection{Additional Studies}

Because the surrogate scouting study described in Sect. 2.1.1 was based on supernate compositions as presented in the Peretz report ${ }^{4}$, and using an MVST supernate sample acquired in 1985, additional studies were performed with surrogate supernates formulated from the analytical data (samples collected from the MVSTs from September 19 to December $5,1989)$ presented in the Sears report 5 . Discussions with evaporator vendors indicated that high $\mathrm{pH}$ could contribute to extreme foaming and that silica in concentrations of greater than $100 \mathrm{mg} / \mathrm{L}$ could create extreme fouling of the heat exchanger surfaces. Therefore, MVST W- 
5

24 and W-28 supernates were selected because these two tanks represent the extremes in $\mathrm{pH}$ (13.1 and 9.1, respectively) and silica content ( $245 \mathrm{mg} / \mathrm{L}$ and $<1.0 \mathrm{mg} / \mathrm{L}$, respectively). The surrogate compositions used in these studies is presented in Table 2.

Table 2. Melton Valley storage tank surrogate supernate composition

\begin{tabular}{|c|c|c|c|c|}
\hline \multirow[b]{2}{*}{ Component } & \multicolumn{2}{|c|}{ W-24 } & \multicolumn{2}{|c|}{ W-28 } \\
\hline & $(g / L)$ & $(\mathrm{mol} / \mathrm{L})$ & $(\mathrm{g} / \mathrm{L})$ & $(\mathrm{mol} / \mathrm{L})$ \\
\hline $\mathrm{NaNO}_{3}$ & 369.80 & 4.35 & 354.50 & 4.17 \\
\hline $\mathrm{KNO}_{3}$ & 28.30 & 0.28 & 66.70 & 0.66 \\
\hline $\mathrm{Na}_{2} \mathrm{CO}_{3}$ & 15.90 & 0.15 & 1.06 & 0.01 \\
\hline $\mathrm{NaCl}$ & 4.27 & 0.07 & 4.09 & 0.07 \\
\hline $\mathrm{NaOH}$ & 0.66 & 0.02 & 0.05 & $<0.01$ \\
\hline $\mathrm{Ca}\left(\mathrm{NO}_{3}\right)_{2} \cdot 4 \mathrm{H}_{2} \mathrm{O}$ & 0.05 & $<0.01$ & 47.23 & 0.20 \\
\hline $\mathrm{MgCl}_{2} \cdot 6 \mathrm{H}_{2} \mathrm{O}$ & 0.01 & $<0.01$ & 13.37 & 0.07 \\
\hline $\mathrm{Na}_{2} \mathrm{SiO}_{3} \cdot 9 \mathrm{H}_{2} \mathrm{O}$ & 2.48 & 0.01 & 0.00 & 0.00 \\
\hline
\end{tabular}

The test equipment and procedures for this series of tests were identical to those used in the tests described in Sect. 2.1.1. Four evaporations were conducted, two each using W-24 and W-28 surrogates. The results are presented in Table 3. 
Table 3. Melton Valley storage tank surrogate soluiion distillation data summary

\begin{tabular}{lcccc}
\hline & \multicolumn{3}{c}{ W-24 } & \multicolumn{3}{c}{ W-28 } \\
\cline { 2 - 5 } & 1 & pH & 3 & 4 \\
\hline Feed & 13.2 & 13.2 & 9.1 & 9.1 \\
Concentrate & 13.4 & 13.4 & 6.7 & 5.2 \\
Distillate & 7.3 & 7.6 & 7.4 & 7.4 \\
& & & & \\
& & Density, g/cc & & 1.264 \\
Feed & 1.246 & 1.244 & 1.275 & 1.389 \\
Concentrate & 1.363 & 1.349 & 1.417 & 1.002 \\
Distillate & 1.002 & 1.003 & 1.002 & 33.5 \\
& & & & 33.7 \\
Percentage of & 32.1 & 32.2 & & \\
volume reduction & & & & \\
\hline
\end{tabular}

These data, with respect to densities and $\mathrm{pH}$, are consistent with the data presented in Table 1. The volume reduction was less than the $38 \%$ achieved with the actual MVST W29 supernate, although the volume reduction achieved continued to merit consideration of evaporation by distillation.

\subsection{VOLUME REDUCTION BY AIR SPARGING AT AMBIENT TEMPERATURE AND PRESSURE}

Evaporation studies were conducted by sparging dry air through a $3.8 \underline{M}$ sodium nitrate solution and actual MVST supernate samples. The sodium nitrate solution was reduced by 50 volume percent, at which time crystals began to form. The $\mathrm{pH}$ of the solution dropped from 11.5 to 6.8 during the evaporation process because of carbonate formation due to 
absorption of carbon dioxide from the sparge air (E. D. Collins, MMES, personal communication to V. L. Fowler, January 28, 1988).

Bench-scale sparging tests were also conducted on supernate samples from six of the MVSTs (samples not available from W-29 and W-30). The volume of water evaporated from the MVSTs before solids began to precipitate ranged from 38 to 55\% (J. F. Walker, MMES, internal communication to T. J. Abraham, June 1988).

These results indicate that significantly higher volume reductions may be possible than are projected from the experiments on W-24 and W-28 surrogates reported in Sect. 2.1.2. The introduction of carbon dioxide by air sparging tends to lower the solution $\mathrm{pH}$, increasing the solubilities of the dissolved salts. Because the MVSTs are currently being sparged with dry air (the in-tank evaporation process), it is important to investigate the significance of this phenomenon for projected volume reductions.

\section{VOLUMEREDUCTION BY BOILING ATSUBATMOSPHERICPRESSURES AND LOW TEMPERATURES}

Based on a study by Bechtel National, Inc. (completed in 1991 under contract to ORNL), a single-stage, motor-driven, vapor compression evaporator was suggested for the OTE process; a proven off-the-shelf evaporator design should be used. Bechtel recommended that scaling and fouling tests be performed before detailed equipment specifications are cumpleted. LICON, Inc., meets these criteria in that its vapor compression evaporators are presently in use at Three Mile Island, unit 2, where over 1 million gal of LLLW has already been successfully processed, and at the Rocky Flats Plant where an estimated 8 million gal of LLLW (solar pond water) will be reduced to less than 10,000 gal. To determine the feasibility of using this type of evaporator (subatmospheric, low temperature) for volume reduction of the ORNL LLLW, Professional Analyses, Inc., contracted with LICON to perform scaling/fouling studies using an MVST surrogate waste 
form. The fouling/scaling studies were conducted at the LICON facilities using a laboratoryscale evaporator unit similar in design to existing nuclear units.

The two surrogate waste forms used in these studies were based on the component concentrations contained in MVST W-24 and W-28, which exhibit the extremes in pH (13.1 and 9.1 , respectively) and silica content $(245 \mathrm{mg} / \mathrm{L}$ and $<1.0 \mathrm{mg} / \mathrm{L}$, respectively). The formulation for these surrogates was presented in Sect. 2.1.2, Table 2. Nine tests were conducted (five with W-24 and four with W-28) using a single-stage low pressure (subatmospheric) evaporator containing $2.1 \mathrm{ft}^{2}$ of heat exchanger surface rated at a nominal 3.0 gph evaporative rate. The evaporator pressures and temperatures tested ranged from $122^{\circ} \mathrm{F}$ and $25 \mathrm{in}$. $\mathrm{Hg}$ (vacuum) to $173^{\circ} \mathrm{F}$ and $19.5 \mathrm{in}$. $\mathrm{Hg}$. Under these operating conditions, the evaporation rates obtained ranged from 0.3 to $2.6 \mathrm{gph}$. Concentration factors of 1.43 ( $30 \%$ volume reduction) were achieved for both surrogates without precipitation of solids when the concentrate was cooled to ambient temperature. No fouling of the heat exchanger tubes occurred and no foaming problems were encountered in any of the tests. Analyses of distillate samples for total dissolved solids were conducted. Solids content ranged from 2.4 to $4.2 \mathrm{mg} / \mathrm{L}$, resulting in an average decontamination factor of $1.9 \times 10^{5}$ (DF = concentrate concentration/distillate concentration).

Assuming that a DF of $1.9 \times 10^{5}$ is achievable for the radionuclides contained in the MVSTs, only ${ }^{137} \mathrm{Cs}$ would exceed the Process Waste Treatment Plant waste acceptance criteria of $400 \mathrm{~Bq} / \mathrm{L}$ in the distillate produced from evaporation of supernate from all eight MVSTs. The ${ }^{137} \mathrm{Cs}$ content would be highest in the distillate produced from $\mathrm{W}-26$, $3,700 \mathrm{~Bq} / \mathrm{L}$.

Surface radiation dose rates for a 5,000 gal capacity tank truck transporting OTE distillate to the Process Waste Treatment Plant have been calculated at $12 \mathrm{mR} / \mathrm{h}$, well below 
the LLLW system waste acceptance criteria of $200 \mathrm{mR} / \mathrm{h}$ surface radiation limit established for tanker and dumpster trucks.

Based upon the performance of the surrogate testing, LICON recommends that a single-effect, hot water or steam-heated evaporator be used for the OTE process. Before the LICON tests, a vapor recompression evaporator was identified as a promising technology because it is being used successfully at Three Mile Island for concentrating boric acid accident water. The testing revealed that the relatively high boiling point elevation ( $18^{\circ} \mathrm{F}$ ) for MVST supernates would largely negate the anticipated energy savings from vapor recompression. The hot water or steam-heated evaporator is mechanically simpler, replacing the vapor compressor with a condenser.

The LICON tests demonstrated that the evaporation could be carried out in the boiling point range of $155-175^{\circ} \mathrm{F}$ with a maximum boiling point elevation of $20^{\circ} \mathrm{F}$ and achieve good evaporation rates with no heat exchanger fouling. The LICON test report is included as the appendix to this report.

\section{PROJECTED LIQUID LOW-LEVEL WASTE VOLUME REDUCTIONS BY THE OUT-OF-TANK EVAPORATION PROCESS}

During the initial evaluation of the OTE process, it was projected that $\sim 120,000 \mathrm{gal}$ of water could be evaporated from the concentrated LLLW at ORNL. The projection was based on an assumption that the eight MVSTs and four of the Bethel Valley service tanks would contain the operational safety requirement limit of $520,000 \mathrm{gal}[351,600 \mathrm{gal}$ of supernate and 168,400 gal of sludge ${ }^{5}$ (D. J. Peterson, MMES, personal communication to V. L. Fowler, Sept. 8, 1992)] at OTE startup. Early feasibility studies indicated the LLLW supernate volume could be reduced by an average of $35 \%$, resulting in a volume reduction of 123,060 gal. Recent tests with surrogates indicate that a $30 \%$ volume reduction is more 
realistic. Evaporation to a volume reduction of $25 \%$ (contingency factor of $5 \%$ ) would result in an increased storage capacity of 87,900 gal.

Recent evaluations (S. M. Robinson, MMES, personal communication to V. L. Fowler, Sept. 7, 1992), based on information from the LLLW data base as of January 1992, indicate that only $211,000 \mathrm{gal}$ of supernate will be available for evaporation at OTE startup. This estimate assumes that (1) 50,000 gal of supernate will be solidified in FY 1993, (2) 11,000 gal will be evaporated by in-tank evaporation in FY 1992 and FY 1993, and (3) no more than 43,000 gal (generator estimates) of LLLW will be generated during FY 1992 and FY 1993. Assuming a maximum $25 \%$ volume reduction, then 52,750 gal of water could be evaporated.

Those volume reduction projections include the assumptions that the sludge volume estimates are correct and that transfers of supernate from supply tanks to the OTE feed tanks (W-29 and W-30) will be complete; that is, tank liquid levels can be pumped down to the supernate/sludge interface.

\subsection{OPERATIONAL TIME REQUIREMENTS}

One proposed operating schedule for the OTE is $24 \mathrm{~h} / \mathrm{day}, 5$ days/week. Assuming an evaporative rate of $30 \mathrm{gal} / \mathrm{h}$, and no down time for maintenance, the time required to evaporate $52,750 \mathrm{gal}$ (minimum projection) is 16 weeks. Thirty-four weeks would be required to evaporate the projected maximum of $123,060 \mathrm{gal}$. Additional time is required for refilling the OTE feed tanks (W-29 and W-30). One operating scenario would require ten transfers, and settling time for bulk solids must be allowed after each transfer. Each transfer would require approximately $8 \mathrm{~h}$. The settling time required, based on data obtained from earlier sedimentation tests ${ }^{6}$, is estimated at about 1 to $2 \mathrm{~h}$ for a 12-ft-diameter MVST. To be conservative, 1 week should be allowed for refilling of the OTE feed tanks and settling of solids before each restart. The total time required for transfers, settling, and evaporation is 
then estimated at 26 to 43 weeks for the projected minimum/maximum volume reductions. With each transfer, supernates will become mixed and lose their individual identity. This change in feed composition will need to be evaluated with respect to the volume of water that can be evaporated from each feed batch. This could be determined during the week-long settling period allowed after each feed rank refill. The operating schedule realistically should follow a $24 \mathrm{~h} /$ day, 7 day/week evaporation schedule to fit the Waste Management Operations shift schedule. Actual operating procedures will be developed before OTE startup.

\section{SUMMMARY AND RECOMMENDATIONS}

Feasibility studies performed to date indicate that the LLLW supernate contained in the Melton Valley an: Bethel Valley storage facilities can be concentrated to near saturation by evaporation of excess water. The volume of water evaporated in tests using surrogate and actual MVST supernate ranged from 30 to $55 \%$ before precipitation of solids occurred. (The range was due to variations in waste composition and $\mathrm{pH}$.) In previous tests, higher volume reductions were attained by sparging with dry air (38 to $55 \%$ ) than by boiling ( 30 to $38 \%$ ). Those results indicate that increased carbonates, due to carbon dioxide absorption from the dry sparge air, decrease the $\mathrm{pH}$ and thus increase the solubility of the dissolved salts. Additional studies are suggesteu ir refine this operating parameter.

All tests to date indicate that the supernate contained in the ORNL LLLW storage tanks can be further concentrated by factors ranging from 1.4 to 2.0 without creating additional solids. The recommended evaporator for removal of excess water from the supernate is a single-stage unit operating at about 20 in. $\mathrm{Hg}$ (vacuum) and at about $170^{\circ} \mathrm{F}$. This temperature reouces the possibility of excessive foaming and minimizes scaling/fouling of the heat exchanger surfaces. 


\section{REFERENCES}

1. Waste Management and Remedial Action Division, Operational Safety Requirements for the Liquid Low-Level Waste System, ORNL/TM-7262/R3, Martin Marietta Energy Systems, Inc., Oak Ridge Natl. Lab., November 10, 1992.

2. S. M. Robinson et al., Status of the ORNL Liquid Low-Level Waste Management Upgrades, ORNL/TM-12299, Martin Marietta Energy Systems, Inc., Oak Ridge Natl. Lab., 1993.

3. J. F. Walker, Jr. et al., In-Tank Evaporation Demonstration Tests. ORNL/TM-12036, Martin Marietta Energy Systems, Inc., Oak Ridge Natl. Lab., October 1992.

4. F. J. Peretz et al., Characterization of Low-Level Liquid Waste at the Oak Ridge National Laboratory, ORNL/TM-10218, Martin Marietta Energy Systems, Inc., Oak Ridge Natl. Lab., December 1986.

5. M. B. Sears et al., Sampling and Analysis of Radioactive Liquid Wastes and Sludges in the Melton Valley and Evaporator Facility Storage Tanks at ORNL, ORNL/TM-11652, Martin Marietta Energy Systems, Inc., Oak Ridge Natl. Lab., September 1990.

6. R. N. Ceo et al., Physical Characterization of Radioactive Sludges in Selected Melton Valley and Evaporator Facility Storage Tanks, ORNL/TM-11653, Martin Marietta Energy Systems, Inc., Oak Ridge Natl. Lab., October 1990. 
Appendix. FINAL REPORT SURROGATE SOLUTION TEST

OAK RIDGE NATIONAL LABORATORY LICON, INC. 
DATE: $\quad$ September 23, 1992

TO: $\quad$ Vic Fowler

Oak Ridge National Lab

FROM: Rod Williamson RlW/Kus

SUBJECT: Authorization to Duplicate Surrogate Solution Test Final Report

Dear Vic:

Please consider this authorization to duplicate our Surrogate Solution Test Final Report for use as an appendix to the volume reduction report you are working on.

REF: RCWOEOSB.kah 
FINAL REPORT SURROGATE SOLUTION TEST

OAR RIDGE NATTONAW LABORATORY

Test for PAI Corporation

116 Milan Way, Oak Ridge, TN 37830

Under Contract DE-AC08-880R21794

Task PAI-002-88

Subcontract No. PAI 8201

Submitted by: LICON, Incorporated

200 E. Government St, Suite 130

Pensacola, FL 32601

Job No. 2107-T

Date: $\quad$ September 8, 1998

Report By: $\quad$ Kenith Grant, Application Enginoer

Testing By: Johnny Cempboll/Konith Grant

Coordinated By: Rodney Williamson, V.P. Sales 
I. INTRODUCTION $\ldots \ldots \ldots \ldots \ldots \ldots \ldots \ldots \ldots \ldots \ldots \ldots \ldots \ldots \ldots$

II. EQUIPMENT DESCRIPTION $\ldots \ldots \ldots \ldots \ldots \ldots \ldots \ldots \ldots \ldots \ldots$

III. TEST CRITERIA $\ldots \ldots \ldots \ldots \ldots \ldots \ldots \ldots \ldots \ldots \ldots \ldots \ldots \ldots \ldots \ldots \ldots$

A. Initial Parameters $\ldots \ldots \ldots \ldots \ldots \ldots \ldots \ldots \ldots \ldots \ldots$
1. Foaming
2. Vapor Velocity
3. Scaling
4. Concentration Ratio
5. Temperature \& Pressure
6. Circulation
7. $\mathrm{pH}$

B. Intermedlate Parameters $\ldots \ldots \ldots \ldots \ldots \ldots \ldots \ldots \ldots \ldots$
1. Foaming
2. Vapor Velocity
3. Scaling
4. Concentration Ratio
5. Temperature \& Pressure
6. Circulation
7. $\mathrm{pH}$

C. Actual Parameters $\ldots \ldots \ldots \ldots \ldots \ldots \ldots \ldots \ldots \ldots \ldots$
1. Foaming
2. Vapor Velocity
3. Scaling
4. Concentration Ratio
5. Evaporator Feed Temperature
6. Circulation Rate
7. $\mathrm{pH}$
8. Temperature \& Pressure (Vapor)

IV. TEST PROGEDURE $\ldots \ldots \ldots \ldots \ldots \ldots \ldots \ldots \ldots \ldots$
A. LICON Standard Test Procedure $\ldots \ldots \ldots \ldots \ldots \ldots \ldots \ldots$
B. PAI Corp. (ORNL) Test Procedure $\ldots \ldots \ldots \ldots \ldots \ldots \ldots$ 
PAGE 2

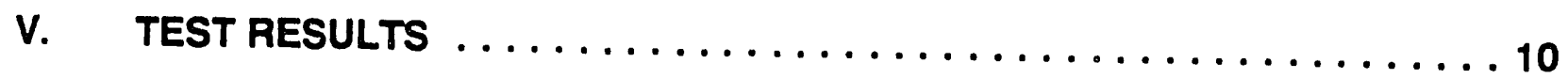

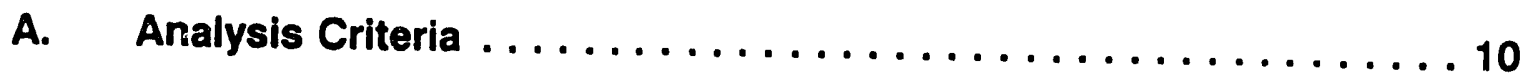

1. Observed Data
a. Foaming
b. Scaling
c. Concentration Ratio

2. Calculated Data
a. Boiling Point Elevation
b. Vapor Velocity

B. Surrogate W-28

1. Observed Data

2. Calculated Data

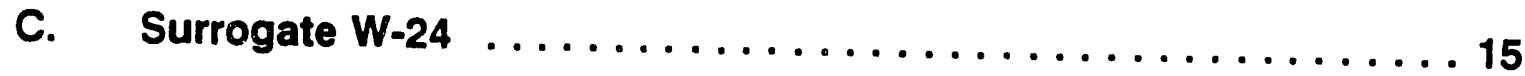

1. Observed Data

2. Calculated Data

3. Steady-State Operation

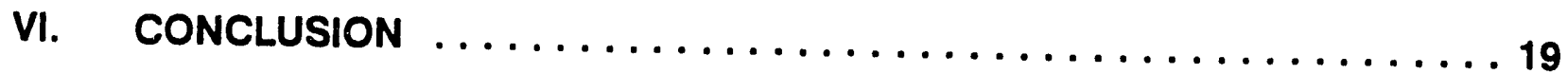

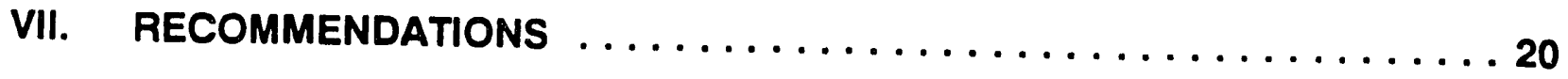

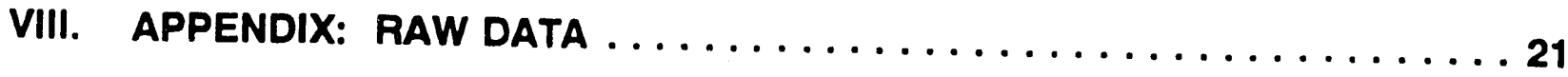
A. Appendix A - Test Results
B. Appendix B - Letters of Correspondence
C. Appendix C - LICON Standard Test Procedure
D. Appendix D - Supernate Compositions
E. Appendix E - Sample Calculations
F. Appendix F - Scale Deposition
G. Appendix G - Flow Diagram 


\section{INTRODUCTION}

On July 16, 1992, PAl Corporation approved execution of testing under Subcontract No. PAI-9201. This authorized LICON, Inc. to begin pilot-testing surrogate samples for evaporation feasibility.

Oak Ridge National Laboratories presently has eight 50,000 gallon storage tanks containing radioactive waste water. Each tank is comprised of approximately $50 \%$ solids and $\mathbf{5 0 \%}$ supernate. It is the intent of ORNL to facilitate additional storage for radioactive waste water without construction of new storage tanks.

Preliminary evaporation tests were performed by PAI Corporation within a laboratory environment at atmospheric conditions. These results suggested that a possible $30 \%$ volume reduction could be achieved through evaporation. Since these initial tests were performed at atmospheric conditions, the possibility for further concentration and or less scale formation at sub-atmospheric conditions were in order.

LICON, Inc. has been requested to analyze volume reduction of the supernate by approximately $30 \%$. A $30 \%$ reduction of supernate would provide an additional 7,500 gallons of storage per tank providing an overall increased capacity of 60,000 gallons.

Feasibility testing was performed on two surrogate samples provided by PAI Corporation. The two test samples provided were modeled after the composition in tanks W-24 and W-28 (Appendix D). Hence, these surrogate samples were given the corresponding designations. From these surrogate samples a series of tests were performed to determine solution characteristics when subjected to subatmospheric evaporation. The physical results of these tests were recorded for analysis and samples of feed, distillate and concentrate returned with Vic Fowler (PAI) and Joe Perona (ORNL) for analysis. The results of the physical analysis are reported here to best predict the necessary design criteria required to accomplish a $30 \%$ supernate volume reduction with an accompanying decontamination factor of at least $10^{5}$. 


\section{EQUIPMENT DESCRIPTION (Refer to Flow Diagram)}

After envisioning the need for waste water volume reduction and recycling, LICON was formed in November 1975. LICON evaporators were designed after nearly 30 patents in seawater distillation. The primary goals were to adapt what was learned in shipboard seawater distillation to a compact, corrosion and scale resistant unit capable of both high purity and high concentration. In 1979 energy efficiency was added to the design criteria.

Although vertical tube arrangements were tried, the idea was abandoned in order to move away from the vertical calandria which required field assembly and made tube removal and cleaning difficult at best. A compact horizontal tube arrangement was the result (101) with twin uptakes into a vertical separator (103). The twin uptakes greatly increase the release area from the surface of the boiling liquor. Vapor lift into the vertical separator allows lighter liquids to be carried up to the separator where some flashing occurs allowing more vapor to flash off and further separating vapor from dissolved ions. This all takes place prior to the vapor going through one to three mist eliminators $(104,105)$. This coupled with optional reversal of vapor flow and vapor washing allows LICON horizontal tube evaporators to obtain excellent decontamination factors, which LICON measures as the difference in the TDS of the distillate versus the TDS (Total Dissolved Solids) of the boiling liquor which is LICON's concentrate.

After passing through the separator distilled water vapor enters a horizontal condenser (102) where cooling water circulating on the inside of a patented bayonet tube arrangement (112) condenses the distilled water vapor on the outside of the tube. This condensed vapor is removed as distilled water along with non-condensible gases by a hydraulically driven venturi jet eductor (406). This discharges into an atmospheric distillate tank (401) where non-condensible vapors are vented and the distilled water accumulates. As the level in the tank rises a float switch (404) opens a solenoid valve (LCV 404) and a portion of the distilled water is pumped out at approximately $40 \mathrm{psig}$. The distilled water is continually monitored by a conductivity meter ( $\mathrm{ClC} 407)$ and is cooled by a distillate cooler (403).

The feed is vacuum dragged into the horizontal evaporator from the concentrate tank (601). Liquid at the bottom of the separator and a portion from the evaporator are continually pumped (602) back to the concentrate tank for recycling. This allows for high recirculation velocities which helps to keep the heat exchanger (110) flushed of solids. The high recirculation rates, low temperature of operation and the use of chemical feed treatments, when necessary allows LICON evaporators to achieve a much higher degree of concentration with less problems and servicing than comparable vertical tube equipment. Heating for this 
lab unit is accomplished by three electric heaters (203). Hot water is circulated by the hot water circulation pump (202). The patented compact bayonet tube design allows for high heat transfer rates which helps in the overall compact design of the system. 


\section{TEST CRITERIA}

During the course of contract negotiations, an initial set of test parameters were proposed by Mr. Rodney Williamson to PAI Corporation (ORNL) on April 28, 1992. These parameters presented by Mr. Williamson underwent a series of changes up to the testing period, July 14,1992 . The following is a record of evolution:

\section{A. Initial Parameters}

The following items are the original parameters proposed by Mr. Williamson for surrogate solution testing:

Test Parameter - April 28, 1992
1. Foaming
2. Vapor Velocity
3. Scaling
4. Concentration Ratio
5. Temperature \& Pressure
6. Circulation Rate
7. $\mathrm{pH}$

* Test criteria is listed in Appendix B; correspondence date April 28, 1992.

\section{B. Intermediate Parameters}

Prior to the arrival of Mr. Fowler and Mr. Perona, July 13,1992, a meeting was held at LICON, Inc. concerning the test parameters from April 28, 1992. In attendance of this meeting were the following:

Robert McElroy John Campbell

Ken Grant
Design Engineer Testing Engineer Applications Engineer 
The results of the meeting are a follows:

Test Parameters - July 13, 1992

1. Foaming

2. Vapor Velocity

3. Scaling

4. Concentration Ratio

5. Temperature \& Pressure

6. Circulation Rate

7. $\mathrm{pH}$

Test Variable/Observed

Test Variable/Observed

Test Variable/Observed

Test Variable/Observed

Test Constant

Test Constant

Test Variable/Observed

* Test Criteria is listed in Appendix B; correspondence date July 13, 1992.

\section{Actual Parameters}

With the arrival of Mr. Fowler and Mr. Perona, testing commenced on July 14,1992 . The following is a listing of the actual data parameters used in the testing of surrogate samples W-24 and W-28:

Test Parameters - July 14, 1992

1. Foaming

2. Vapor Velocity

3. Scaling

4. Concentration Ratio

5. Evaporator Feed Temp.

6. Circulation Rate

7. $\mathrm{pH}$

8. Pressure (Vapor) \& Temp.
Test Variable/Observed Test Variable/Observed Test Variable/Observed Test Variable/Observed Test Constant Test Constant Test Constant Test Variable

* Test data located in Appendix A.

As listed, the test parameters underwent several changes up to the actual test themselves. Nine tests were performed; Five on surrogate W-24, and four on surrogate $W-28$. A steady state test of six hours was added to the high silica water of W-24 (Test \#6). It was determined that the pH of both samples was to be held constant. Also the circulation rate as well as evaporative feed temperature were to be held constant. These three input parameters numbers five, six and seven would allow for proper emphasis on surrogate characteristics three, four and eight under sub-atmospheric evaporation. For a given set of test constants, data was to be collected which would determine concentration ratio, vapor velocity, and scaling. Observations concerning foaming and/or foam characteristics were also 
within the test criteria. The evaporator tube bundle was weighed before and after every test to detect minute scale formation. In adjition to the listed parameters, distillate conductivity was continually monitored. Varying the temperature and therefore the pressure would indicate if this had any effect upon the distillate conductivity or scaling. This additional data was used to facilitate sub-atmospheric evaporation feasibility. Since different technicians may vary operation of the equipment slightly, three other tests were added and run by Kenith Grant to check the consistency of the previous tests. These tests, one on $W-28$ test \#9 at $153^{\circ} \mathrm{F}$, and two on $W$ 24 tests $\# 7$ at $157^{\circ} \mathrm{F}$ and $\# 8$ at $133^{\circ} \mathrm{F}$, confirmed the results of the previous tests by weighing both the concentrate and the distillate produced. 


\section{TEST PROCEDURE}

\section{A. LICON Standard Test Procedure (Refer to Appendix C) \\ B. PAI Corporation (ORNL) Test Procedure}

During the period from July 14, 1992 to July 20,1992 a series of five tests were conducted. Two tests were performed on surrogate W-24 while three tests were performed on surrogate W-28. Beifore each test, the C-3 was flushed clean with city water. The titanium tube bundle in the evaporator was dried then weighed. When testing was complete, the bundle was removed again for weighing to determine possible scale formation. Distillate and concentrate $\mathrm{pH}$ was monitored during testing. Apart from these procedures, test data collection was identical to that during a standard test. To verify vapor velocity calculations and other recorded data, three additional tests were run during the week of August 31. During these tests the tube bundle was not weighed. 


\section{TEST RESULTS}

\section{A. Analysis Criteria}

Testing of surrogate samples W-24 and W-28 were conducted under standard LICON conditions. Interpreting the results of the testing gave way to two categoris:

\section{Observed Data}

Data under this category is collected and interpreted directly. One example of observed data is foaming. During operation, the test operator views the evaporator chamber and separator through sight windows. Foaming characteristics are recorded. Detrimental foam carryover can be viewed through the separator window and incidental foalning can be viewed and judged in the evaporator sight window. The testing of surrogates W-24 and W-28 involved three observed data parameters.

a. Foaming

The preserice of foam is almost always associated with higher pH's and lower concentrations, however high pH's do not always mean that foaming will be a detrimental problem. Foaming is simply observed in the areas cited above, as well as in the concentrate tank.

b. Scaling

The evaporator tube bundle is removed, dried, and weighed before and after each test to determine scale deposition, except for tests 7,8 and 9 as noted.

c. Concentration Ratio

A predetermined sample is processed through the C-3 until precipitation of solids begin to occur. When saturation is achieved, testing is complete. The ratio of remaining concentrate to initial concentrate volume is referred to as the concentration ratio. Concentration ratio during tests 7,8 and 9 was not the primary objective, so tests were terminated prior to the precipitation of solids. 
2. Calculated Data

Calculated data is what the name implies, and is determined through raw data collection. When the operator records raw data during a test, this data is analyzed and processed using applicable formulas to determine a physical result. This result is referred to as calculated data. Surrogates W-24 and W-28 were tested for boiling point elevation and vapor velocities.

a. Boiling Point Elevation (BPE)

Boiling point elevation is the difference between the vapor temperature and the solution temperature. Generally as dissolved ions increase the boiling point of the liquid increases, as is the case with salt water. This boiling point rise takes additional energy and is a critical factor in designing evaporators.

b. Vapor Velocity

Velocity at which the vapor produced during distillation travels is determined by specific volume at saturation temperature, production rate of distillate, and cross sectional area of travel (Figure 1). High vapor velocities can have a detrimental effect on decontamination factors and to low a vapor velocity can bring contamination over by simple Brownian Motion.

*Note: $\quad$ Refer to Appendix E for sample calculations.

\section{B. Surrogate W-28 (Non-Silica) (See Test Charts 1, 2 and 9, and 5)}

A series of three tests, numbers 1,2 and 5 , were performed on the W-28 surrogate. Each test started with five gallons and was operated at a different pressure and therefore vapor temperature. In addition, test 9 was run to further verify results. From the results submitted it becomes easily apparent that the low temperature tests do not offer any improvement in decon or scale formation, so the data generated is dealt with in only a rudimentary manner.

1. Observed Data (Foaming, Vapor Velocity, Scaling, Concentration and Conductivity)

During testing of the W-28 surrogate, no foaming was observed at any time. This was somewhat to be expected with a surrogate 
solution with no surfactants present. Due to the relatively high salt concentration in the Melton Valley Storage Tanks, foaming is not expected to be a problem there either, with or without the presence of surfactants. At no time did the vapor velocity appear to be bringing contaminated liquor over into the distillate. Weight measurements of the evaporator tube bundle to a thousandth of a pound or a tenth of a gram before and after each test revealed no scale formation. A maximum concentration ratio of $2.0: 1$ was achieved during test number 5 allowing for an approximate $40-50 \%$ volume reduction of the $\mathrm{W}-28$ surrogate.

2. Calculated Data (Production, BPE, and Vapor Velocity)

The test chart lists the values for production, boiling point elevation, vapor velocity, and the recorded conductivity in microsemmens. As expected, the data collected reveals increasing BPE with increasing concentration. The data reveals that salting out takes place between 18 and $20^{\circ} \mathrm{F}$ BPE regardless of the operating temperatures. However, tests run in 1979 with more accurate instrumentation by the University of West Virginia on chromic acid and cyanide solutions revealed that decreasing temperatures do decrease BPE slightly. These tests revealed that there are no significant differences.

There was also no apparent correlation between vapor velocities and distillate quality. Although exceeding design velocities of the mesh would most certainly decrease distillate quality, it should be noticed that starting and sometimes ending distillate quality will be somewhat higher. The starting quality is due to absorbed $\mathrm{CO}_{2}$ in the distillate and the ending quality can be affected by high levels at equipment shutdown and the force of the breaking vacuum pulling some contaminants over.

Test number 5 shows an unusually high distillate production rate in relation to the similar operating temperatures of tests 3 and 7 . LICON has no explanation of this except perhaps as an error in data collection. We would have repeated the test, but saw no point in it since operating in the $130-138^{\circ}$ vapor temperature range showed no benefits. 
TEST \# 1 - W-28

JULY 14, 1992

\begin{tabular}{||c|c|c|c|c|c|}
\hline TIME & $\begin{array}{c}\text { VAPOR TEMP. } \\
(\circ \mathrm{F})\end{array}$ & $\begin{array}{c}\text { PROD. RATE } \\
(\mathrm{\circ} / \mathrm{HR})\end{array}$ & $\begin{array}{c}\text { BPE }\left(^{\circ} \mathrm{F}\right) \\
\Delta \mathrm{T}: \mathrm{T}-6 \& \mathrm{~T}-7\end{array}$ & $\begin{array}{c}\text { VAPOR VEL. } \\
(\mathrm{F} / \mathrm{s})\end{array}$ & $\begin{array}{c}\text { CONDUCTIVITY } \\
\text { MICRO }-\% / \mathrm{cm}\end{array}$ \\
\hline 1400 & 118 & N/A & 4 & N/A & 2.3 \\
\hline 1500 & 116 & N/A & 7 & N/A & 1.4 \\
\hline 1600 & 117 & N/A & 8 & N/A & 1.3 \\
\hline
\end{tabular}

TESTS \# 2 \& \# 9 - W-28

JULY 15 \& SEPT. 1, 1992

\begin{tabular}{|c|c|c|c|c|c||}
\hline TIME & $\begin{array}{c}\text { VAPOR TEMP. } \\
(\circ \mathrm{F})\end{array}$ & $\begin{array}{c}\text { PROD. RATE } \\
(\% / \mathrm{HR})\end{array}$ & $\begin{array}{c}\text { BPE }\left({ }^{\circ} \mathrm{F}\right) \\
\Delta \mathrm{T}: \mathrm{T}-6 \& \mathrm{~T}-7\end{array}$ & $\begin{array}{c}\text { VAPOR VEL. } \\
(\mathrm{F} / \mathrm{s})\end{array}$ & $\begin{array}{c}\text { CONDUCTIVITY } \\
\text { MICRO }-\% \mathrm{~cm}\end{array}$ \\
\hline 1405 & 157 & 8.34 & 11 & $\mathrm{~N} / \mathrm{A}$ & 2.9 \\
\hline 1425 & 154 & 12.51 & 15 & 6.71 & 2.5 \\
\hline \hline$\# 9$ & & & & & 2.2 \\
\hline 1430 & 153 & 10.15 & 9 & 5.56 & \\
\hline
\end{tabular}


TEST \# 5- W-28

JULY 20, 1992

\begin{tabular}{|c|c|c|c|c|c|}
\hline TIME & $\begin{array}{c}\text { VAPOR } \\
\text { TEMP. (०F) }\end{array}$ & $\begin{array}{c}\text { PROD. RATE } \\
(1 / \mathrm{HF})\end{array}$ & $\begin{array}{c}\text { BPE (०F) } \\
\Delta T: T-6 \& \text { T-7 }\end{array}$ & $\begin{array}{c}\text { VAPOR VEL. } \\
(\mathrm{F} / \mathrm{s})\end{array}$ & $\begin{array}{c}\text { CONDUCTIVITY } \\
\text { MICRO }-\% / \mathrm{cm}\end{array}$ \\
\hline 1430 & 138 & 16.68 & 9 & 13.0 & 1.2 \\
\hline
\end{tabular}


C. Surrogate W-24 (with Silica) (See test charts 3 and $7 \& 4$ and 8 )

Three tests were performed on the W-24 surrogate. Two tests, numbers 3 and 4, emphasized boiling point elevation vapor velocity characteristics and decontamination between the concentrate and the distillate while the third test (Test \# 6) " concentrated on steady-state operation and scale formation within a range of concentration ratios. Tests numbers 7 and 8 were run by a different operator to further verify the results. Each test was started with five gallons of feed. The following are the results of the tests:

1. Observed Data

As in the case of the W-28 surrogate solution, the W-24 revealed no foaming tendencies. Weight measurements of the tube bundle before and after each test revealed no scaling tendencies. A maximum concentration ratio of 2.0 to 1 was achieved allowing for an approximate $40-50 \%$ reduction of the $W-24$ surrogate. These concentration ratios will later be confirmed by water analysis. During the number six test addtional salt build-up was noticed on the heat exchanger, however this was not attached as scale.

2. Calculated Data

As discovered in the testing of W-28, the W-24 boiling point elevation increased as saturation was approached. Other data showed no significant difference between W-28 tests.

3. Steady State Operation

The primary purpose behind Test \# 6 was to determine the characteristics of W-24 under steady state operation. It was requested that further inquiry into the possible formation of scale be pursued. The presence of silica within the W-24 surrogate had no significant affect upon the titanium tube bundle after eleven hours of steady state operation. Careful observation of the W-24 surrogate contents in comparison to the W-24 supernate contents provided by PAl Corporation, revealed the presence of several metal elements within the actual W-24 supernate samples. The presence of these metal elements suggest that the actual contents of the tank might

* Raw data for Test \# 6 is listed in Appendix F. 
give rise to scaling problems. Further studies into this area revealed that as long as the pH of the W-24 supernate was maintained between $11-11.5$, there should be no scale formation".

The results of Test \# 6 were based on a 20 - $45 \%$ volume reduction. The W-24 surrogate was concentrated to $20 \%$ which equates to one gallon of distillate removal from a 5 gallon test sample. Once the $20 \%$ concentration was achieved, the distillate dump (TC5) was directed back into the concentrate tank (601). This plumbing modification allowed Test \# 6 to simulate steady-state operation at a minimum concentration of $20 \%$ increasing to a maximum concentration of approximately $40 \%$ right before the distillate is transferred. Operating at these concentration levels allowed for a scaling study at steady state conditions. Also, the boiling point elevation could be analyzed at steady-state conditions for anticipated levels of concentration. 


\section{TESTS \# 3 \& \# 7 - W-24}

JULY 16 \& AUGUST 31, 1992

\begin{tabular}{|c|c|c|c|c|c||}
\hline TIME & $\begin{array}{c}\text { VAPOR TEMP. } \\
(\circ \mathrm{F})\end{array}$ & $\begin{array}{c}\text { PROD. RATE } \\
(\% / \mathrm{HR})\end{array}$ & $\begin{array}{c}\text { BPE }(\circ \mathrm{F}) \\
\Delta \mathrm{T}: \mathrm{T}-6 \text { \& } \mathrm{T}-7\end{array}$ & $\begin{array}{c}\text { VAPOR VEL. } \\
(\mathrm{F} / \mathrm{s})\end{array}$ & $\begin{array}{c}\text { CONDUCTIVITY } \\
\text { MICRO }-\% / \mathrm{cm}\end{array}$ \\
\hline 1000 & 141 & $\mathrm{~N} / \mathrm{A}$ & 8 & $\mathrm{~N} / \mathrm{A}$ & 2.1 \\
\hline 1030 & 138 & 8.34 & 11 & 6.5 & 0.8 \\
\hline 1100 & 135 & 8.34 & 14 & 7.0 & 0.6 \\
\hline 1118 & 132 & $\mathrm{~N} / \mathrm{A}$ & 18 & $\mathrm{~N} / \mathrm{A}$ & 1.1 \\
\hline \hline$\# 7$ & & & & & 2.6 \\
\hline 1325 & 134 & 3.15 & 6 & 2.7 & \\
\hline
\end{tabular}

TESTS \# 4 \& \# 8 - W-24

JULY 16 \& SEPT. 1, 1992

\begin{tabular}{|c|c|c|c|c|c|}
\hline $\begin{array}{c}\text { TIME } \\
\# 4\end{array}$ & $\begin{array}{l}\text { VAPOR TEMP. } \\
\left({ }^{\circ} \mathrm{F}\right)\end{array}$ & $\begin{array}{c}\text { PROD. RATE } \\
\left(\% /{ }_{\text {HA }}\right)\end{array}$ & $\begin{array}{c}\mathrm{BPE}\left({ }^{\circ} \mathrm{F}\right) \\
\Delta \mathrm{T}: \mathrm{T}-6 \text { \& } \mathrm{T}-7\end{array}$ & $\begin{array}{l}\text { VAPOR VEL. } \\
(F / / s)\end{array}$ & $\begin{array}{l}\text { CONDUCTIVITY } \\
\text { MICRO }-\% / \mathrm{cm}\end{array}$ \\
\hline 1440 & 161 & N/A & 10 & N/A & -.. \\
\hline 1455 & 160 & 16.68 & 12 & 7.8 & 1.2 \\
\hline 1520 & 155 & 13.01 & 18 & 6.8 & 1.4 \\
\hline $\begin{array}{c}\# 8 \\
0900\end{array}$ & 159 & 13.29 & 11 & 6.35 & 1.4 \\
\hline
\end{tabular}


TEST \# 6 - W-24

AUGUST 20, 1992

\begin{tabular}{|c|c|c|c|c|c|}
\hline TIME & $\begin{array}{c}\text { VAPOR } \\
\text { TEMP. }\left({ }^{\circ} F\right)\end{array}$ & $\begin{array}{c}\text { PROD. RATE } \\
(1 / \mathrm{HA})\end{array}$ & $\begin{array}{c}\text { BPE }\left({ }^{\circ} F\right) \\
\Delta T: T-6 \& T-7\end{array}$ & $\begin{array}{c}\text { VAPOR VEL } \\
((1 / /))\end{array}$ & $\begin{array}{l}\text { CONDUCTIVITY } \\
\text { MICRO }-\% / \mathrm{cm}\end{array}$ \\
\hline 1400 & 138 & Recycled Dist. & 9 & N/A & 8 \\
\hline 1500 & 137 & Recycled Dist. & 11 & N/A & 10 \\
\hline 1600 & 139 & Recycled Dist. & 12 & N/A & 7 \\
\hline 1700 & 133 & Recycled Dist. & 9 & N/A & 10 \\
\hline 0919 & 146 & Recycled Dist. & 6 & N/A & 9 \\
\hline 1017 & 146 & Recycled Dist. & 8 & N/A & 8 \\
\hline 1107 & 148 & Recycled Dist. & 6 & N/A & 8 \\
\hline 1210 & 146 & Recycled Dist. & 7 & N/A & 7 \\
\hline 1338 & 147 & Recycled Dist. & 5 & N/A & 6 \\
\hline 1430 & 147 & Recycled Dist. & 6 & N/A & 5.8 \\
\hline 1525 & 148 & Recycled Dist. & 6 & N/A & 5.9 \\
\hline
\end{tabular}




\section{v. CONCLUSION}

The data and observations collected from nine tests involving two surrogate solutions allows for confident replies concerning treatment by evaporation. Data from these tests support the premise that volume reduction by approximately $30 \%$ is attainable through sub-atmospheric evaporation. The results also show that steady-state operation at concentration levels ranging from $20 \%$ to $40 \%$ can be achieved and maintained with minimal scale formation, as applied to the surrogate test solution. Computer analysis contained in Appendix $F$ indicates that scaling of the W-24 tank could be controlled with simple pH adjustment. The gradual increase in BPE as the concentration increases suggests that a simple temperature differential controller maybe the easiest way to control the concentrate extraction. As soon as crystals form the BPE drops. Therefore monitoring the vapor temperature and the concentration recycle temperature differential will allow a set point to be established to start a concentrate extraction pump. Test data reveals that between $18-20^{\circ}$ BPE precipitation occurs. Although the decontamination factors were good and acceptable further improvements are always welcomed and these will be addressed in the recommendations.

The percent volume reduction is figured as the amount of distillate produced divided by the starting feed volume which was always five gallons. The decon factors, as calculated by PAl, are shown in Appendix A dated 8/19/92 by Vic Fowler. Since actual DF will be dependent upon chemical analysis, this data was not duplicated in the body of the report.

Vapor velocities indicate that there are no significant distillate conductivity improvements with lower vapor velocities in the operating temperature ranges that were studied. Standard LICON design for separator and mesh velocities will be maintained in the design for this evaporator. PAl Corporation and Oak Ridge National Laboratories should be confident in further pursuits into implementing vacuum evaporation for volume reduction of radioactive wastewater.

During test number 6 , the exchanger was first rubbed by hand to remove any nonattached salt, then weighed. The difference in weight was $2.355 \mathrm{lbs}$ at the start and $2.358 \mathrm{lbs}$. at the finish. This difference is not significant and can be explained by non-attached salt. It does tell us, however that in the design of the operational unit, it would be helpful to have a distilled water spray flush on top of the tube bundle at shut down to wash salt build up off the bundle. This could also be controlled by concentrate removal prior to saturation.

* Note: Refer to Appendix F for test data and observations. 


\section{RECOMMENDATIONS}

As a result of numerous meetings and telephone conversations, several issues have been addressed with regard to the final design of this evaporator. It is LICON's recommendation that a single-effect, hot water or steam heated evaporator be used. Based upon the performance of the surrogate testing, the only modifications that we would recommend are vapor washing, spray flushing of the evaporator, deflector plates on the vapor uptakes and reversal of flow of the vapor prior to condensation. All but flushing the evaporator have to do with acheiving better decontamination. The unit should be designed to operate in the range of $155-175^{\circ} \mathrm{F}$ vapor temperature with a maximum of $20^{\circ} \mathrm{F}$ boiling point elevation.

Final decisions need to be made by ORNL with regard to evaporative capacity and the support services, such as hot water heating or steam and cooling towers or radiators. Also, the amount of and area of shielding need to be defined. LICON would recommend that just the evaporator and concentrate portion be lead shielded. Total automation of the system will allow remote operation, and with the use of dual concentrate pumps and possibly eductors, maintenance will be further minimized. With proper research and engineering, volume reduction of the radioactive supernate will be successful. 


\section{APPENDICES}




\section{APPENDIX A}

TEST RESULTS: SURROGATE W-24 \& W-28 JULY 23, 1992 
July 23, 1992

Mr. Vic Fowler

Mr. Joe Perona

Oak Ridge National Lab.

Bldg. 3017

P. O. Box 2008

Oak Ridge, TN 37831-6342

REF: Pilot Testing on Surrogate Solutions

for PAl Corporation

Subcontract No. PAl-9201

Gentlemen:

We at LCON want to thank you for confidence in our company and your assistance during the pilot testing at our Pensacola facility. As you witnessed, the test results were exceptional and point toward a successful installation.

The following are observations and procedures obtained through the feasibility study.

1. Mixing

There was some $\mathrm{pH}$ changes noticed after mixing each drum's contents prior to testing. I do not believe the changes would affect the evaporator's performance, but is listed here as incidental information.

Drum W-29jin

Drum W-28
Before mixing $11.7 \mathrm{pH}$

After mixing $11.6 \mathrm{pH}$

Before mixing $8.3 \mathrm{pH}$

After mixing $8.8 \mathrm{pH}$

2. Foaming Results

$\begin{array}{ll}\text { Test \#1 } & \text { No foam } \\ \text { Test \#2 } & \text { No foam } \\ \text { Test \#3 } & \text { No foam } \\ \text { Test \#4 } & \text { No foam } \\ \text { Test \#5 } & \text { No foam }\end{array}$


Page 2

July 23, 1992

\section{Concentration Ratios}

According to the reduction ratios at the point of salting out, the only variable is the operating temperatures. We were able to obtain higher reduction numbers at higher temperatures because the solubility increased as well.

4. Vapor Velocitios

The separation performance did not vary significantly as the velocities changed in sink with the vapor temperatures.

5. Variation of $\mathrm{pH}$

The results were so territic on the $2 \mathrm{pH}$ variations provided, it was deemed by all to be satisfactory and further variance unnecessary.

6. Scaling Tendencies

With the samples provided, there was no scaling observed or measured after any of the tests. After each test, the bundle would be removed and water rinsed to dissolve any salt crystals. The cleaning did not involve the scrubbing of the tube surfaces at any time. The assembly was air dried before weighing.

REF: Johnny $>3016 . t e b$ 


\section{LICON INCORPORATED \\ LOG SHEET \\ PILOT EVAPORATION/CONCENTRATION TEST}

Test $F 1 \quad$ CUENT: Oak Ridge National Lab JOB\# 2107-T

\begin{tabular}{|c|c|c|c|c|c|c|}
\hline DATE: $\left.J_{u}\right|_{y} 14,1992$ & $11: 00$ & $12: 00$ & $2: 00$ & $3: 00$ & $4: 00$ & \\
\hline TEMPERATURES: & & & & & & \\
\hline T-1 CONDENSERIN & 91 & 90 & 86 & 89 & 88 & \\
\hline T-2 CONDENSER OUT & 96 & 92 & 87 & 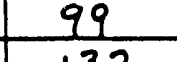 & $\frac{98}{123}$ & \\
\hline T-3 EVAPORATOR OUT & 128 & 118 & 129 & 132 & 133 & \\
\hline T-4 EVAPORATORIN & 128 & 118 & 129 & 133 & 133 & \\
\hline T-5 DISTILATE & 104 & 107 & 110 & 109 & 114 & \\
\hline T-6 VAPOR & 116 & 112 & 118 & 116 & 117 & $78^{\circ} B P E$ \\
\hline T-7 CONC. RECYCLE & 122 & 116 & 125 & 124 & 125 & \\
\hline T-8 EVAPORATOR FEED & 119 & 115 & 123 & 122 & 123 & \\
\hline ELOWS: & & & & & & \\
\hline 605 FEED (GPH) & 50 & $\frac{60}{30}$ & 60 & 60 & 60 & \\
\hline COOLNG WATER (GPH) & 30 & 30 & 90 & 60 & 60 & \\
\hline & & & & & & \\
\hline $\begin{array}{l}\text { P1 DISTILLATE PUMP } \\
\text { P2 COOUNG PUMP }\end{array}$ & $\frac{35}{39}$ & $\frac{35}{39}$ & $\frac{35}{21}$ & $\frac{35}{45}$ & $\frac{35}{45}$ & \\
\hline P3 HEATING PUMP & 11 & 11 & 11 & 10 & 10 & \\
\hline C1 VACUUM & 26 & 26 & 25 & $\frac{25}{6}$ & $\frac{25}{0.6}$ & \\
\hline C2 CONC. PUMP & $0-5$ & $0-5$ & 0.5 & $0-5$ & 0.5 & \\
\hline TOTALAMPS & N.A. & $=$ & & & & \\
\hline VOLTAGE & 220 & 二 & & & & \\
\hline HOUR METER READING & $\mu . A$. & $\overline{-}$ & & & & \\
\hline $\begin{array}{l}\text { VOLUME CHECK } \\
407 \text { CONDUCTNITY Milloas } \\
\text { Micro } 5 / \mathrm{cm}\end{array}$ & $\overline{16.5}$ & $=$ & 2.3 & 1.4 & 1.3 & \\
\hline SAMPLE & & & 2 & $\frac{1}{3}$ & 4 & \\
\hline DISTILLATE PH & N.A. & & 8.3 & 8.0 & 8.0 & \\
\hline CONCENTRATE PH & 8.2 & & 7.8 & 7.7 & 7,5 & \\
\hline
\end{tabular}

NOTES:
W-28 Surrogate
5 gallons lnitial volume

Feed Sample pH 8.8

Temperature increased at 12:00

Initial Evaporator Heat Exchanger Weight 1070 grams

Heat Exchanger Weight after pilot test 1070 grams operator Joha D. Cample II Project manaGer Gohn D. Camphell 


\section{LICON INCORPORATED \\ LOG SHEET \\ PILOT EVAPORATION/CONCENTRATION TEST}

Test \#1

CUENT: OaKRidge National Lob JOB\# 2107-T

DATE: July 15,1992

\begin{tabular}{|l|l|}
\hline $9: 30$ & $9: 45$ \\
\hline
\end{tabular}

TEMPERATURES:

T-1 CONDENSERIN

$T-2$ CONDENSER OUT

$T-3$ EVAPORATOR OUT

T-4 EVAPORATORIN

T-5 DISTIULATE

T-6 VAPOR

T-7 CONC. RECYCLE

T-8 EVAPORATOR FEED

\begin{tabular}{c|c}
91 & 91 \\
\hline 91 & 99 \\
\hline 130 & 142 \\
130 & 143 \\
& \\
\hline 122 & 120 \\
136 & 135 \\
\hline 129 & \\
\end{tabular}

FLOWS:

605 FEED (GPH)

COOUNG WATER (GPH)

\begin{tabular}{|l|l|}
\hline 60 & 60 \\
\hline 60 & 60
\end{tabular}

PRESSURES:

P1 DISTILLATE PUMP

P2 COOLNG PUMP

P3 HEATING PUMP

C1 VACUUM

C2 CONC. PUMP

\begin{tabular}{c|c|c}
35 & 35 \\
\hline 45 & 45 \\
\hline 10 & 10 \\
25 & 25 \\
\hline $0-5$ & $0-5$
\end{tabular}

TOTAL AMPS

VOLTAGE

HOUR METER READING

VOLUME CHECK Gallons

407 CONDUCTNITY Micro $5 / \mathrm{cm}$

SAMPLE

DISTILLATEPH

CONCENTRATEPH

\begin{tabular}{|l|l|} 
& \\
\hline & \\
\hline 1.75 & \\
\hline 11.0 & 1.5 \\
\hline $5,6^{7}$ & $7^{*}, 8$ \\
\hline & \\
\hline
\end{tabular}

NOTES:

* Denotes concentrate sample Test restarted at 9i/5 Salt formation at 9:45

OPERATOR John D. Campbell PROJECT MANAGER 


\section{LICON INCORPORATED}

\section{LOG SHEET}

\section{PILOT EVAPORATION/CONCENTRATION TEST}

\section{Test 2}

DATE: July 15,1992

TIME:

CUENT: O.K Ridge National Lab JOB*2107-T

TEMPERATURES:

$T-1$ CONDENSERIN

$T-2$ CONDENSER OUT

T-3 EVAPORATOROUT

T-4 EVAPORATORIN

T-5 DISTILATE

T-6 VAPOA

T-7 CONC. RECYCLE

T-8 EVAPORATOR FEED
- $F$

\begin{tabular}{l|l|l|l|l}
$1: 35$ & $2: 05$ & $2: 20$ & $2: 25$ & $2: 48$
\end{tabular}

FLOWS:

605 FEED (GPH)

COOUNG WATER (GPH)

\begin{tabular}{|c|c|c|c|c|}
\hline 87 & 88 & & 87 & \\
\hline 121 & 124 & & 122 & \\
\hline 178 & 180 & & 180 & \\
\hline 183 & 183 & & 182 & \\
\hline 136 & 147 & & 144 & \\
\hline 153 & 157 & & 154 & \\
\hline 162 & 168 & & 169 & $15^{\circ}$ BPE \\
\hline 150 & 163 & & 165 & \\
\hline
\end{tabular}

PRESSURES:

\begin{tabular}{|c|c|c|c|c|c|}
\hline P1 DISTILATE PUMP & 35 & 35 & & 35 & \\
\hline P2 COOUNG PUMP & 49 & 49 & & 49 & \\
\hline $\begin{array}{l}\text { P3 HEATING PUMP } \\
\end{array}$ & $7-8$ & 10 & & $7-8$ & \\
\hline CI VACUUM & 20.5 & 20.5 & & 20.5 & \\
\hline C2 CONC. PUMP & $5-10$ & $5-10$ & & $5-10$ & \\
\hline \multicolumn{6}{|l|}{ TOTALAMPS } \\
\hline \multicolumn{6}{|l|}{ VOLTAGE } \\
\hline \multicolumn{6}{|l|}{ HOUR METER READING } \\
\hline VOLUME CHECK Tank level & .75 & 1.25 & 1.63 & 1.75 & 2.25 \\
\hline 407 CONDUCTNITY micro $5 / \mathrm{cm}$ & 3.2 & 2.9 & & 2.5 & 3.1 \\
\hline SAMPLE & I & 2 & $3 \%$ & $+4,5$ & $\times 6,7$ \\
\hline DISTILATEPH & 27 & 7,4 & & & \\
\hline CONCENTRATE PH & 7,5 & 7.5 & & & \\
\hline
\end{tabular}

NOTES:

* Denotes Concentrate sample

$2: 48$ Salting out in evaporator, Test Terminated $20^{\circ} \mathrm{BPE}$

Evaporator heat exchanger "after test" weight $=1070$ grams No Scaling

operator Joha D. Cample ll

PRoject manager Gola D.

Sargell

200 EAST GOVERNMENT STREET • SUITE 130 - PENSACOLA. FL 32501 - (TEL) 904/45-5738 • (FAX) 904/438-2040 


\section{LICON INCORPORATED \\ LOG SHEET \\ PILOT EVAPORATION/CONCENTRATION TEST}

Test \# 3 CUENT: OaK Ridge National Lab JOB\# 2107-T

\begin{tabular}{|c|c|c|c|c|c|c|}
\hline $\begin{array}{lllll}\text { DATE: } J_{u} T_{y} & 16 & 1992 \\
\end{array}$ & & & & & & \\
\hline TIME: & $9: 30$ & $10: 00$ & $10: 30$ & $11: 00$ & $11: 18$ & $11: 26$ \\
\hline TEMPERATURES: & & & & & & \\
\hline T-1 CONDENSER IN & 88 & 87 & 87 & 87 & 88 & \\
\hline T-2 CONDENSER OUT & 116 & 111 & 110 & 108 & 107 & \\
\hline T-3 EVAPORATOR OUT & 162 & 158 & 159 & 158 & 159 & \\
\hline T-4 EVAPORATORIN & 166 & 160 & 161 & 160 & 160 & \\
\hline T-5 DISTIUATE & 128 & 132 & 130 & 128 & 125 & \\
\hline T-6 VAPOA & 143 & 141 & 138 & 135 & 132 & 131 \\
\hline T-7 CONC. RECYCLE & 150 & 149 & 149 & 149 & 150 & 149 \\
\hline T-8 EVAPORATOR FEED & 135 & 146 & 146 & 146 & 147 & \\
\hline FLOWS: & & & & & & \\
\hline 605 FEED (GPH) & 60 & 60 & 60 & 60 & 60 & \\
\hline COOUNG WATER (GPH) & 60 & 60 & 60 & 60 & 60 & \\
\hline PRESSURES: & & & & & & \\
\hline P1 DISTILLATE PUMP & 35 & 35 & 35 & 35.5 & 35 & \\
\hline P2 COOUNG PUMP & 50 & 46 & 46 & 46,5 & 46.5 & \\
\hline P3 HEATING PUMP & 11 & $\frac{12}{12}$ & 12 & 11,5 & 13 & \\
\hline C1 VACUUM & 22.5 & 22.5 & 23.0 & 23.0 & 23.5 & \\
\hline C2 CONC. PUMP & $5-10$ & $7-12$ & $7-12$ & $7-12$ & $7-12$ & \\
\hline TOTAL AMPS & 230 & & & & & \\
\hline VOLTAGE & 220 & & & & & \\
\hline HOURMETER READING & N.A & & & & & \\
\hline VOLUME CHECK & - & .5 & 1.0 & 1.5 & 1.75 & 1.8 \\
\hline 407 CONDUCTNITY micro $5 / \mathrm{cm}$ & 7.8 & 2,1 & 0.8 & 0.6 & 1.1 & 7.4 \\
\hline SAMPLE & 1 & 2 & 3 & 4.5 & 6,7 & 89 \\
\hline DISTILATEPH & 8.5 & 7,9 & 7.3 & & & \\
\hline CONCENTRATEPH & 1160 & & & & & \\
\hline NOTES: $S_{a}$ & $11:=$ & & B & $=$ & $F$ & $\omega-24$ \\
\hline Scaling & & & & & & \\
\hline Heat Exchanger & eight & after & st & 70 & $m s$ & \\
\hline operator John D. Car & ell & PROJEC & $A G E$ & Cose & $\int_{a \infty}$ & O \\
\hline
\end{tabular}

200 EAST GOVERNMENT STREET • SUITE 130 - PENSACOLA. FL 32501 • (TEL) 904/438-5738 • (FAX) 904/438-2040 


\section{LICON INCORPORATED}

LOG SHEET

\section{PILOT EVAPORATION/CONCENTRATION TEST}

Test 4

DATE: July 16,1992

TIME:

CUENT: OaK Ridge National Lab JOB\# 2107-T

\begin{tabular}{|l}
\hline TEMPERATURES: \\
\hline$T-1$ CONDENSERIN \\
\hline
\end{tabular}

$T-2$ CONDENSER OUT

T-3 EVAPORATOROUT

T-4 EVAPORATORIN

T-5 DISTILATE

T-6 VAPOR

T-7 CONC. RECYCLE

T-8 EVAPORATOR FEED

\begin{tabular}{|l|l|l|l|l|}
\hline $2: 25$ & $2: 40$ & $2: 55$ & $3: 05$ & $3: 20$ \\
\hline
\end{tabular}

FLOWS:

605 FEED (GPH)

COOUNG WATER (GPH)

\begin{tabular}{|c|c|c|c|c|c|}
\hline 89 & 89 & 88 & & 89 & \\
\hline 124 & 125 & 124 & & 123 & \\
\hline 186 & 185 & 184 & & 186 & \\
\hline 192 & 189 & 190 & & 189 & \\
144 & 151 & 150 & & 147 & \\
\hline 160 & 161 & 160 & 158 & 155 & \\
\hline 168 & 171 & 172 & 173 & 173 & \\
\hline 155 & 166 & 167 & & 169 & \\
\hline 155 & &
\end{tabular}

PRESSURES:

P1 DISTILLATE PUMP

P2 COOUNG PUMP

P3 HEATING PUMP

CI VACUUM

C2 CONC. PUMP

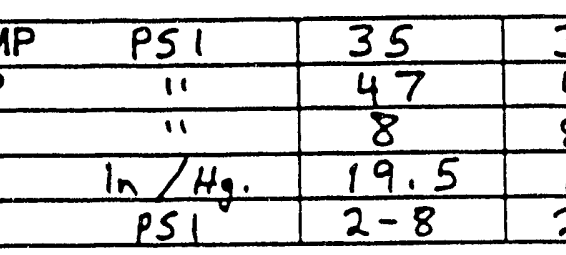

\begin{tabular}{|l|l|l|l|l}
\hline 60 & 60 & 60 & 60 & 60 \\
60 & 60 & 60 & 60 & 60
\end{tabular}

TOTAL AMPS

VOLTAGE

HOUR METER READING

VOLUME CHECK

407 CONDUCTNITY micre $5 / \mathrm{cm}$

SAMPLE

DISTILATEPH

CONCENTRATEPH

35
$\frac{37}{8}$
$\frac{19.0}{2-8}$

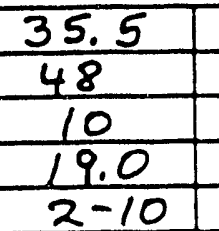

\begin{tabular}{|c|}
\hline 35 \\
48 \\
10 \\
20.0 \\
\hline $2-10$ \\
\hline
\end{tabular}

NOTES:

$$
\begin{aligned}
& \text { Salting out at } 3: 20 \quad \text { B.P.E }=18^{\circ} \mathrm{F} \quad \omega-24 \\
& \text { No Ssaling }
\end{aligned}
$$

Heat Exchanga weight after test

1070 grams

operator John D. Campbell project manager Gohre D. Caopebell

200 EAST GOVERNMENT STREeT • SUITE 130 - PENSACOLA. FL 32501 - (TEL) 9044/438-5736 - (FAX) 804/436-2040 
VLF 8-19-92

\section{OTE: Preliminary Evaluation From LICON Tests:}

W-24 Surrogate: Feed TDS $=405,665 \mathrm{mg} / \mathrm{L}, \mathrm{pH}=12.8, \mathrm{Si}=210 \mathrm{mg} / \mathrm{L}$

W-28 Surrogate: Feed TDS $=391,836 \mathrm{mg} / \mathrm{L}, \mathrm{pH}=9.1, \mathrm{Si}=<0.2 \mathrm{mg} / \mathrm{L}$

\begin{tabular}{cccccccc} 
Test No. & $\begin{array}{c}\text { Vol. Red. } \\
(\%)\end{array}$ & $\begin{array}{c}\text { Evap. Press. } \\
(\text { (Hg) }\end{array}$ & $\begin{array}{c}\text { Conc. Temp. } \\
(\cdot \mathrm{F})\end{array}$ & $\begin{array}{c}\text { Vapor Temp. } \\
(\cdot \mathrm{F})\end{array}$ & $\begin{array}{c}\text { Recycle } \\
\text { Rate (GPH) }\end{array}$ & $\begin{array}{c}\text { Evaporation } \\
\text { Rate (GPH) }\end{array}$ & $\begin{array}{c}\text { DF** } \\
(\text { Conc./Dist.) }\end{array}$ \\
\hline \#1, W-28 & -30 & 25.0 & 136.0 & 122.0 & 60.0 & 0.32 & $1.4 \times 10^{5}$ \\
\#2, W-28 & -30 & 20.5 & 169.0 & 154.0 & 50.0 & 1.85 & $2.2 \times 10^{5}$ \\
\#3, W-24 & -30 & 23.5. & 150.0 & 132.0 & 60.0 & 0.95 & $2.3 \times 10^{5}$ \\
\#4, W-24 & -30 & 19.5 & 173.0 & 155.0 & 60.0 & 2.62 & $1.9 \times 10^{5}$
\end{tabular}

\section{Comments:}

-No Foaming Problems during any Test.

- No Scaling/Fouling of HX surfaces occurred (2.08 $\mathrm{ft}^{2} \mathrm{HX}$ Surface)

- Volume Reduction, $\%=($ Dist./Feed $) 100$

.. Decontamination Factor $(\mathrm{DF})=$ Conc. $/$ Dist., based on TDS 


\section{Sample Solids Content and Densities}

\begin{tabular}{ccccccc} 
& \multicolumn{2}{c}{ FEED } & \multicolumn{2}{c}{ Concentrate $^{*}$} & \multicolumn{2}{c}{ Distillate $^{*}$} \\
\cline { 2 - 7 } Test No. & $\begin{array}{c}\text { TDS } \\
(\mathrm{mg} / \mathrm{L})\end{array}$ & $\begin{array}{c}\text { Density } \\
(\mathrm{g} / \mathrm{mL})\end{array}$ & $\begin{array}{c}\text { TDS } \\
(\mathrm{mg} / \mathrm{L})\end{array}$ & $\begin{array}{c}\text { Density } \\
(\mathrm{g} / \mathrm{mL})\end{array}$ & $\begin{array}{c}\text { TDS } \\
(\mathrm{mg} / \mathrm{L})\end{array}$ & $\begin{array}{c}\text { Density } \\
(\mathrm{g} / \mathrm{mL})\end{array}$ \\
\hline \#1, W-28 & 391,386 & 1.266 & 579,521 & 1.454 & 4.23 & 1.005 \\
\#2. W-28 & 391,386 & 1.266 & 579.521 & 1.444 & 2.66 & 1.002 \\
\#3, W-24 & 405,665 & 1.236 & 559,765 & 1.414 & 2.41 & 1.004 \\
\#4. W-24 & 405.665 & 1.236 & 559,765 & 1.391 & 2.91 & 1.004
\end{tabular}

Analytical data trom samples attained at a Volume Reduction of $-30 \%$. 


\section{LICON INCORPORATED}

\section{LOG SHEET}

\section{PILOT EVAPORATION/CONCENTRATION TEST}

Test $\$ 5$

CUENT: Oak Ridge National LabjoB\# 2107.T

DATE: $\quad 7-20-92$

TIME:

\begin{tabular}{l|l|l|l|}
$14: 00$ & $14: 30$ & $14: 45$ & 1500 \\
\hline
\end{tabular}

TEMPERATURES:

${ }^{\circ} \mathrm{F}$

T-1 CONDENSER IN

$T-2$ CONDENSER OUT

T-3 EVAPORATOR OUT

T-4 EVAPORATORIN

T-5 DISTILLATE

T-6 VAPOR

T-7 CONC. RECYCLE

T-8 EVAPORATOR FEED

\begin{tabular}{|c|c|c|}
\hline & 118 & 125 \\
\hline & 120 & 127 \\
\hline & 154 & 163 \\
\hline & 157 & 167 \\
\hline & 118 & 129 \\
\hline & 1317 & 138 \\
\hline & 138.7 & $149] 19$ \\
\hline & 126 & 145 \\
\hline
\end{tabular}

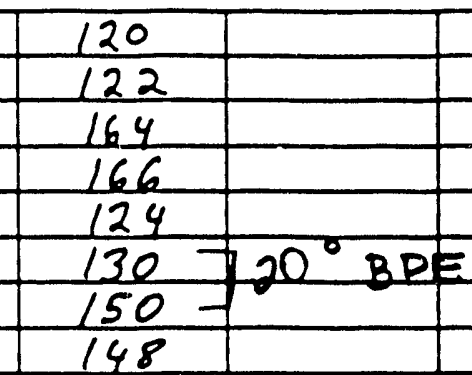

FLOWS:

605 FEED (GPH)

COOUNG WATER (GPH)

\begin{tabular}{|l|l|}
\hline 45 & 60 \\
\hline 60 & 60 \\
\hline
\end{tabular}

60

PRESSURES:

P1 DISTILLATE PUMP

P2 COOUNG PUMP

P3 HEATING PUMP

C1 VACUUM

C2 CONC. PUMP

\begin{tabular}{|c|c|c|}
\hline & 36 & 36 \\
\hline & 18 & 18 \\
& 14 & 14 \\
& 24 & 23 \\
& 10 & 5
\end{tabular}

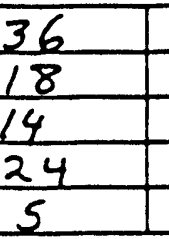

TOTAL AMPS

VOLTAGE

HOUR METER READING

VOLUME CHECK

407 CONDUCTNITY

SAMPLE

DISTILATE PH

CONCENTRATE PH

\begin{tabular}{|c|c|c|c|}
\hline & & & \\
\hline 20.4 & 21.0 & & 214 \\
\hline 0.5 & 1.5 & & 2.75 \\
\hline 2.4 & 1.2 & 1.8 & 36.4 \\
\hline 1 & 2 & 3 & 4 \\
\hline 8,7 & 8.02 & 8.45 & 8.35 \\
\hline 7.39 & 6.52 & 6.48 & 6.35 \\
\hline
\end{tabular}

NOTES:

W.28 No foaming No scále Salting out at $40-50 \%$ ceduction

OPERATOR Mike House project manager fohn \%. Camphell 
8/20/92 CUENT: OAK RIDGE NAT: LABS JOBH 2107-T

DATE: AUG 20,92

TIME: STRRTUP 1230

$1400-1500$

$1600+1700$

SHUT DOWN 1700 HRS

TEMPERATURES:

T-1 CONDENSERIN

T-2 CONDENSER OUT

T-3 EVAPORATOROUT

T-4 EVAPORATORIN

T-5 DISTIULATE

T-6 VAPOR

T-7 CONC. RECYCLE

T-8 EVAPOAATORFEED

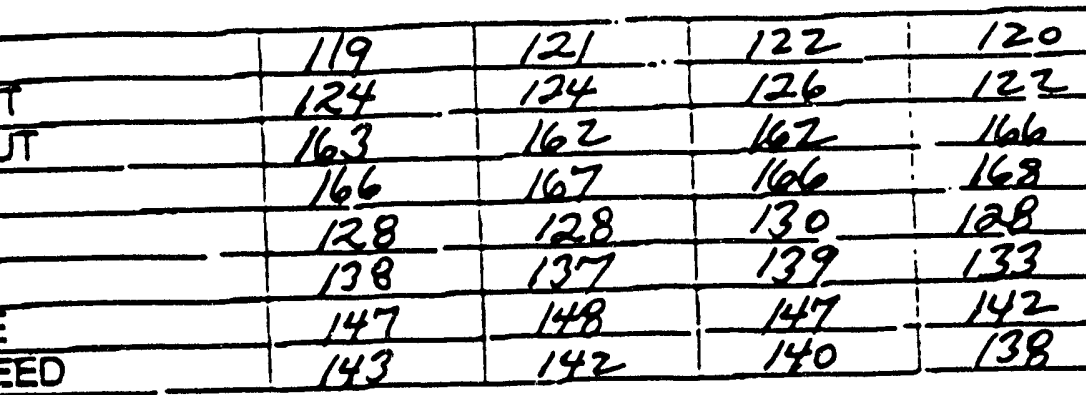

FLOWS:

GOS FEED (GPH) "IM

COOUNGWATER GPF

\begin{tabular}{|l|l|}
\hline 0.75 & 0.25 \\
\hline 7.5 & 4.0 \\
\hline
\end{tabular}

$0.50: 0.50$

$7.0+7.0$

\section{HRESSURES:}

PI DISTILLATE PUMP

P2 COOUNG PUMP

P3 HEATING PUMP

C1 VACUUM

C2 CONC. PUMP

\begin{tabular}{l|c|c|c|c|}
\hline & 35 & 35 & 35 & 35 \\
\hline$P P$ & 26 & 20 & 20 & 20 \\
\hline 10 & 9 & 9 & 9 \\
\hline $123^{\prime \prime}$ & $23^{\prime \prime}$ & $23^{\prime \prime}$ & $23^{\prime \prime}$ \\
\hline & 5 & 2 & 3 & 3 \\
\hline
\end{tabular}

TOTAL AMPS

VOLTAGE

HOUR METER READING

VOLUME CHECK

407 CONDUCTNITY 11 i :M

SAMPLE

DISTILLATEPH

CONCENTRATE PH

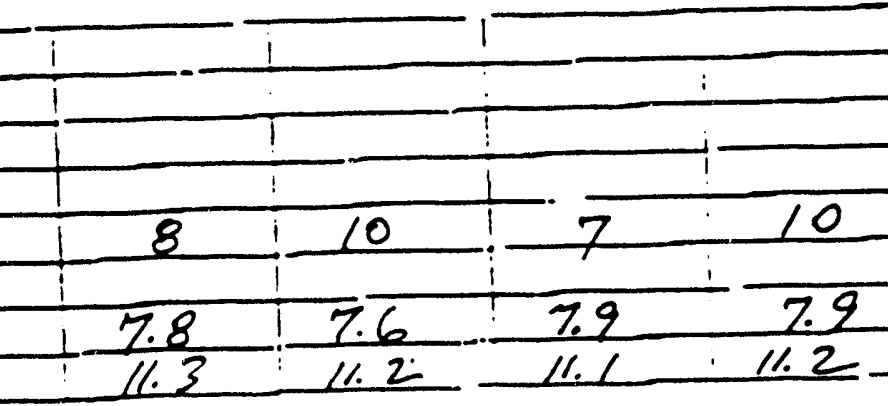

* w- 24 SURROGATE

NOTES.

* TUBE BUNDLE waS PULED AND WEICGED REEORE TOT THRE RUNQLE WELCHF $\equiv 2.355 .165$

+5 GALON SAMPLE $w-24$

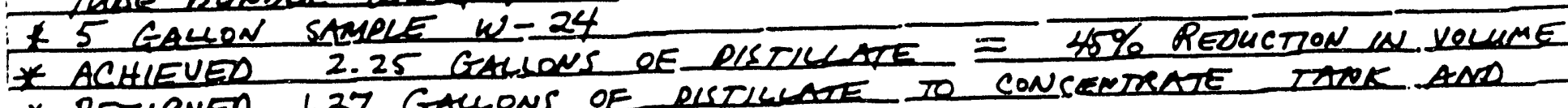

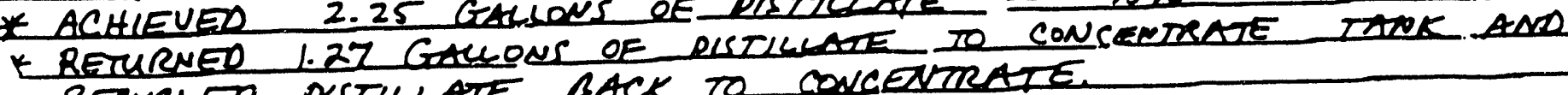
RECYCLEP DXSTJLLATE BACK TO CONCENTRATE.

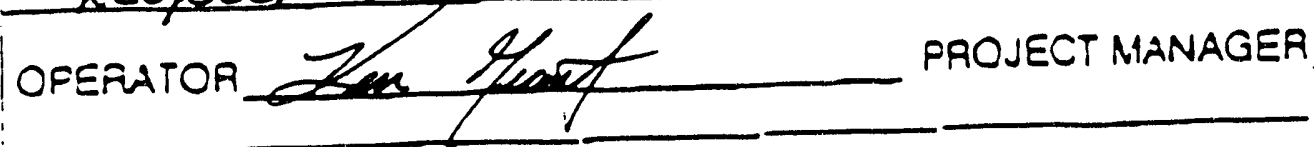




\section{LICON INCORPORATED \\ LOG SHEET \\ PILOT EVAPORATION/CONCENTRATION TEST \\ TEST \#6 \\ Cowtinued \\ $8 / 24 / 92$}

8/24/92 CUENT: OAK RIDGE NAT LABS JOB\# 2107-T

PAGEI

DATE: AUG. 24,92

TIME: 0830 START UP

10919

\begin{tabular}{l|l|l|}
\hline 1017 & 1107 & 1210 \\
\hline
\end{tabular}

1338 1430

TEMPERATURES:

T-1 CONDENSERIN

$T-2$ CONDENSER OUT

$T-3$ EVAPOAATOROUT

T-4 EVAPORATORIN

T-5 DISTIULATE

T-6 VAPOR

$T-7$ CONC. RECYCLE

T-8 EVAPOAATORFEED

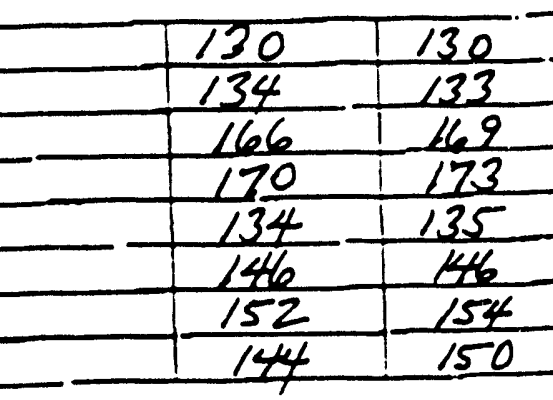

\begin{tabular}{|l|l|l}
132 & 130 & 130 \\
\hline 134 & 132 & 132 \\
\hline 168 & 168 & 166 \\
172 & 172 & 168 \\
\hline 137 & 136 & 136 \\
148 & 146 & 147 \\
\hline 154 & 153 & 152 \\
\hline 151 & 144 & 151 \\
\hline
\end{tabular}

$13 \overline{3}$ 131

Flows:

605 FEED (GPH) TPM

COOUNG WATEA (GPA)

$\sin \quad$\begin{tabular}{c|c}
\hline 2.9 & 0 \\
9 &
\end{tabular}

\begin{tabular}{l|r}
9 & 0.9 \\
\hline
\end{tabular}

0.9

0.9

9

0.9

RESSURES:

: RESSURES:

P2 COOLNG PUMP

P3 HEATING PUMP

C1 VACUUM

C2 CONC. PUMP

\begin{tabular}{|c|c|c|c|c|c|}
\hline & 35 & 35 & 35 & 35 & 35 \\
\hline 33 & 33 & 34 & 33 & 133 & \\
\hline 10 & 9 & 9 & 9 & 9 & 9 \\
\hline $22^{\prime \prime}$ & "22" & $22^{\prime \prime}$ & $2 z^{\prime \prime}$ & $22^{\prime \prime}$ & $22^{\circ}$ \\
\hline & 2 & 1.5 & 1.5 & 1.5 & \\
\hline
\end{tabular}

\section{TOTAL AMPS}

VOLTAGE

HOUR METER READING

VOLUME CHECK

407 CONOUCTNITY $115 / \mathrm{cm}$

DISTIULATEPH

CONCENTRATE PH

$-\frac{1}{1}$

1

\begin{tabular}{c:c}
\hline & \\
\hline 9 & 8 \\
\hline$\frac{7.1}{11.1}$ & $\frac{7.1}{11.0}$
\end{tabular}

i

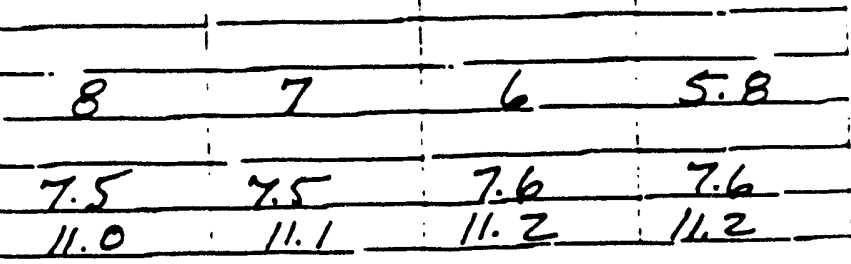

*w-24 suRROGATE

NOTES. GALLUS OF CONCENTRATE RUN THROUCH THE C-3Q $20 \%$ CR.

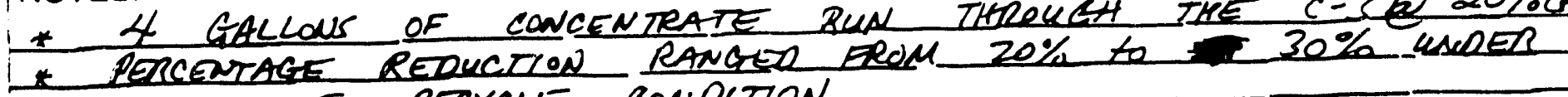
* DLSTILCATE RECYCLE CONDITION.

!OPERATOR

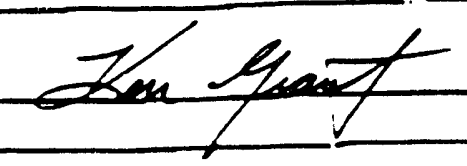

PROJECT MANAGER 


\section{LICON INCORPORATED \\ LOG SHEET \\ PILOT EVAPORATION/CONCENTRATION TEST

\section{$8 / 24 / 92$ \\ CUENT: ORNL}

PAGE 2

DATE: AUC 24, 92

TIME:

TEMPERATURES:

T-1 CONDENSERIN

T-2 CONDENSER OUT

T-3 EVAPOAATOROUT

T-4 EVAPORATORIN

T-5 DISTIULATE

T-6 VAPOR

T-7 CONC. RECYCLE

T-8 EVAPORATORFEED
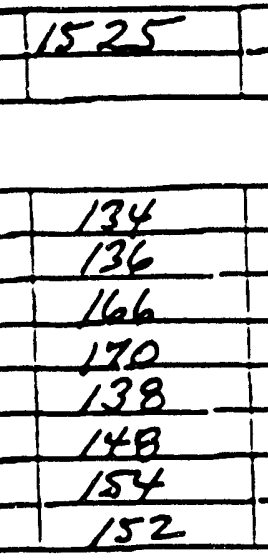

JOB* 2107-T

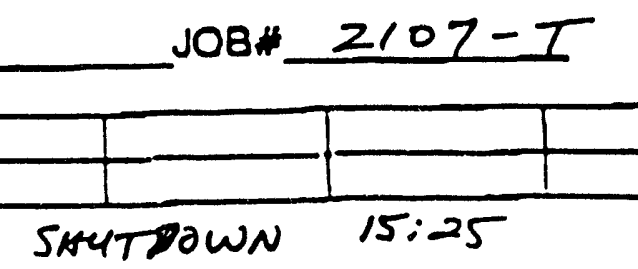

SHUTDOWN 15:25

\section{FLWS:}

605 FEED (GPH)

COOUNGWATER FAMA EM!
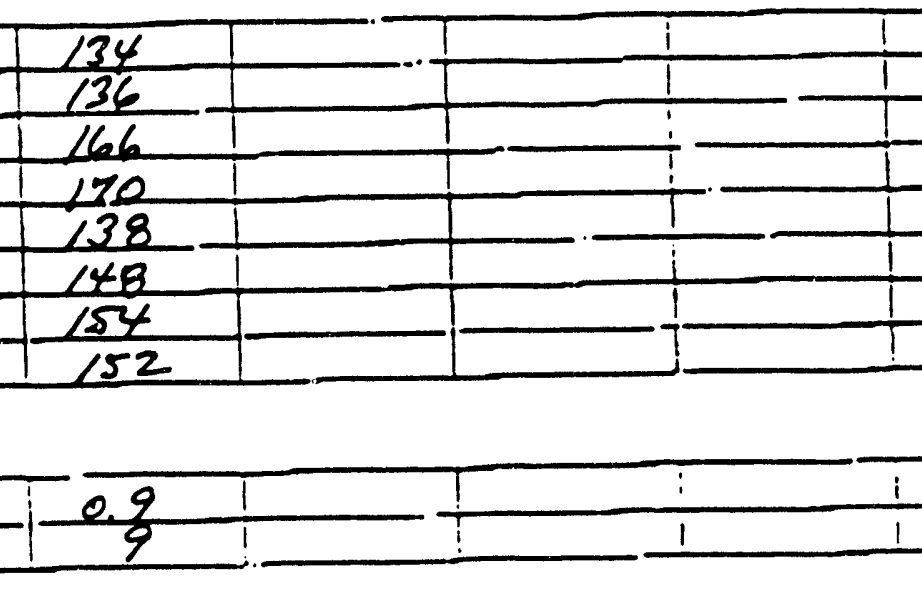

TRESSURES:

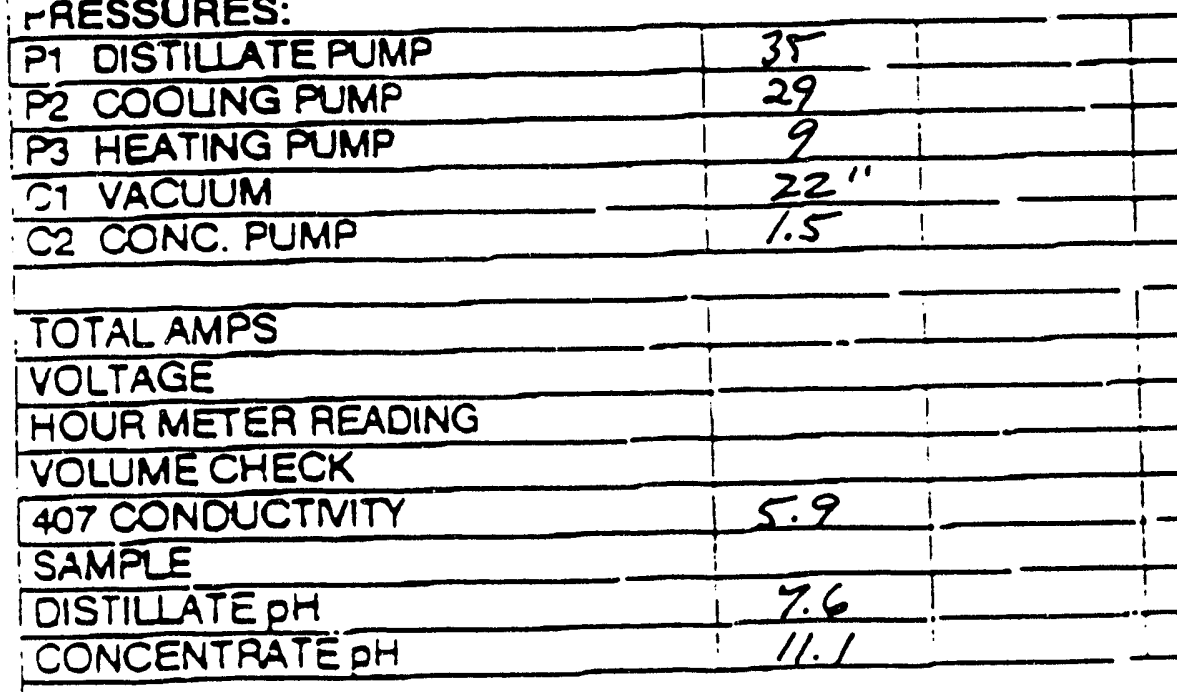

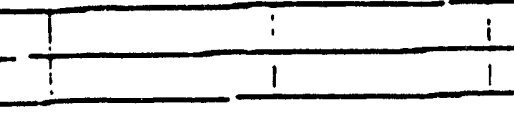

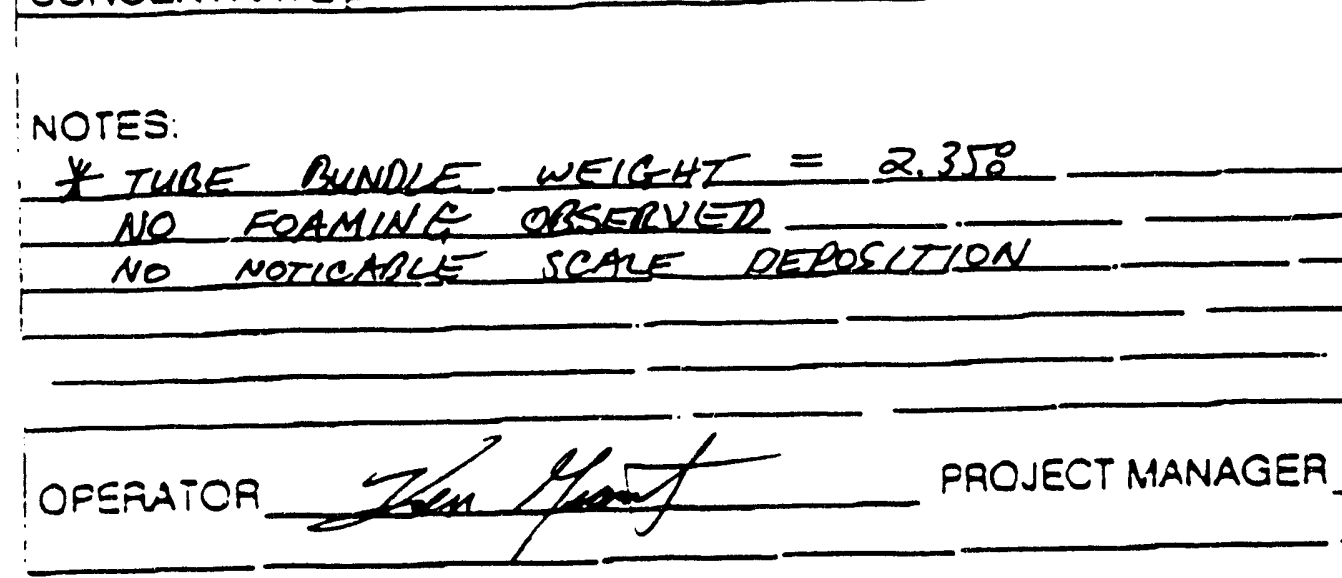




\section{LICON INCORPORATED \\ LOG SHEET \\ PILOT EVAPORATION/CONCENTRATION TEST}

TESTF 7

CLIENT: OAK RIOGE NAT. LABS JOB\# $2107-T$

\begin{tabular}{|c|c|c|c|c|c|c|}
\hline AUG-US 31.92 & & & & & & \\
\hline TIME: STARTUP 1055 & $1 / 25$ & 1225 & 1325 & 1435 & & \\
\hline $\begin{array}{l}\text { SHUT DOWN } 145 / \\
\text { TEMPERATURES: }\end{array}$ & & & & & & \\
\hline$T-1$ CONDENSERIN & 123 & 124 & 125 & 125 & & \\
\hline T-2 CONDENSER OUT & 125 & 126 & 127 & 127 & & \\
\hline T-3 EVAPORATOR OUT & 150 & 152 & 151 & 151 & & \\
\hline T-4 EVAPORATORIN & 152 & 154 & 153 & 153 & & \\
\hline T-5 DISTILLATE & 128 & 129 & 130 & 130 & & \\
\hline T-6 VAPOR & 133 & 133 & 134 & 134 & & \\
\hline T-7 CONC. RECYCLE & 138 & 140 & 140 & 141 & & \\
\hline T-8 EVAPORATOR FEED & 134 & 137 & 137 & 138 & & \\
\hline LOWS: & & & & & & \\
\hline 605 FEED (GPH) & 30 & 24 & 24 & 24 & & \\
\hline COOUNG WATER (GPH) & 180 & 180 & 150 & 120 & & \\
\hline ES: & & & & & & \\
\hline P1 DISTILATE PUMP & 35 & 35 & 35 & 35 & & \\
\hline P2 COOUNG PUMP & 18 & 13 & 14 & 14 & & \\
\hline P3 HEATING PUMP & 14 & 14 & 14 & 14 & & \\
\hline C1 VACUUM & 24 & 23 & 23 & 23 & & \\
\hline C2 CONC. PUMP & 2 & 2 & 2 & 2 & & \\
\hline
\end{tabular}

TOTAL AMPS

VOLTAGE

HOUR METER READING

VOLUME CHECK

407 CONDUCTNITY $\mu s / \mathrm{cm}$

SAMPLE

DISTILATE $p H$

CONCENTRATE $\mathrm{pH}$

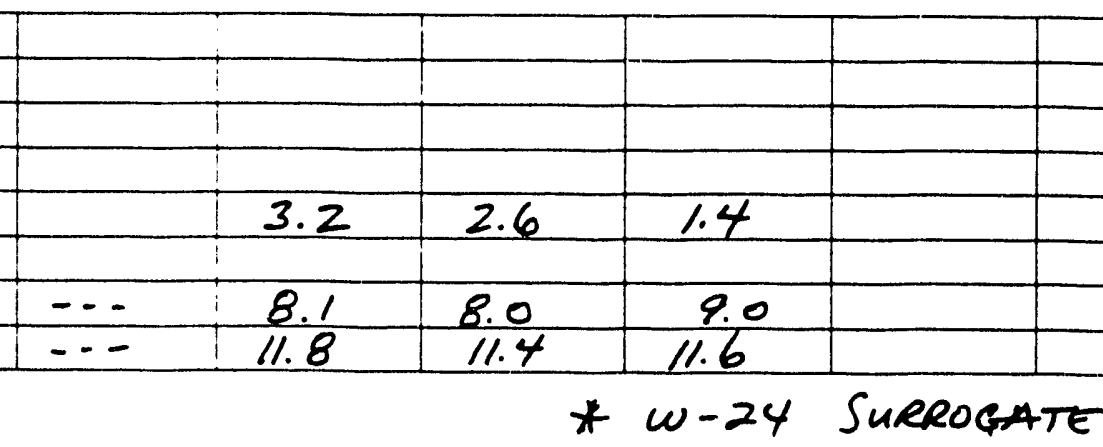

NOTES:

SAMPLE WEIEHT - 46.898165

CONCENTRATE WT. $\approx 33.334 \mathrm{lhS}-$ LOSSES DUE TO TRANSFER

DSTTILLATE PRoOUCED - $10.982 \mathrm{lbS}$ - BETWEEN 1125 - 1451 AVERAGE PRODUCTION - $0.38 \mathrm{GPH}$

VoLume ReDUCTION $=23.4 \%$

VOLUME REDUCTION $=$ DIST PROD. SAMPLE WT.

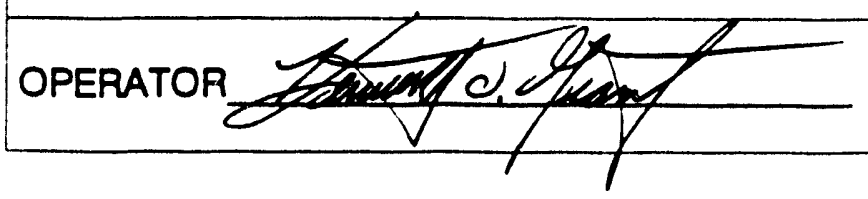
PROJECT MANAGER

200 EAST GOVERNMENT STREET • SUITE 130 • PENSACOLA, FL $32501 \cdot$ (TEL) 904/434-5088 • (FAX) 904/438-2040 


\section{LICON INCORPORATED \\ LOG SHEET \\ PILOT EVAPORATION/CONCENTRATION TEST}

TEST \#8

CLIENT: OAK RIPGE NAT. LABS JOB\# Z1OY -T

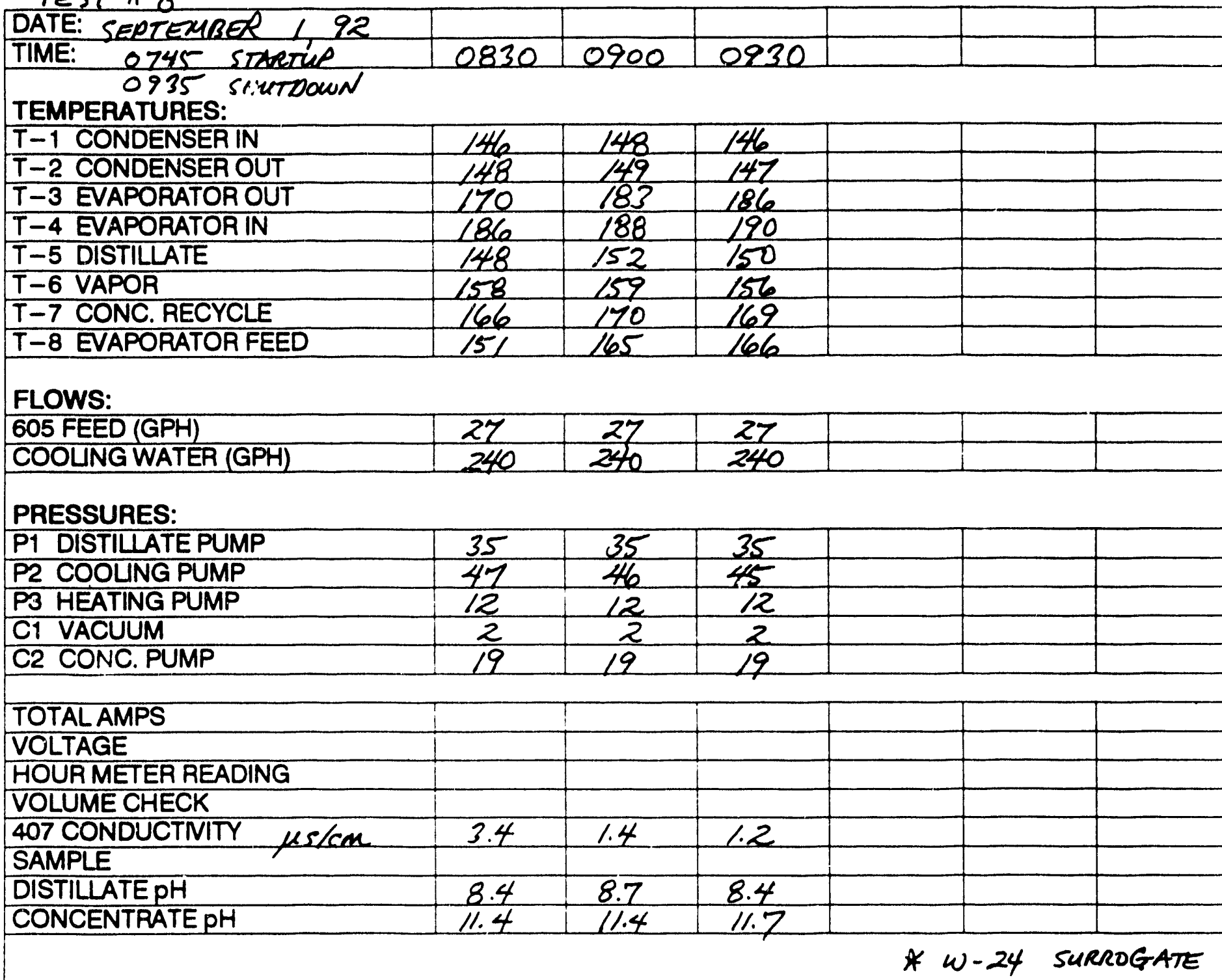

NOTES:

SAMPLE WEIGHT - 44.062165

CONCENTRATE WT. $\approx 23.728 / \mathrm{hS}$ - LOSSES DUE TO TRAWSFER

DISTILCATE ProDuces - 19.936 llss. - BETwEeN 0800-0230 AveTAGE Pronuction - 1.6 GPS

VQume REDUCTION - $45.2 \%$ VOL. RER $=$ DSTT PROD.

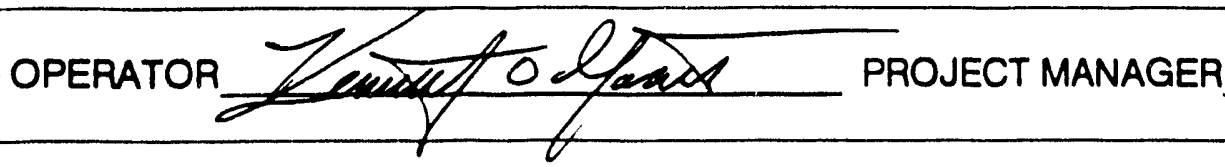

200 EAST GOVERNMENT STREET • SUITE 130 • PENSACOLA, FL 32501 • (TEL) 904/434-5088 • (FAX) 904/438-2040 


\section{LICON INCORPORATED \\ LOG SHEET \\ PILOT EVAPORATION/CONCENTRATION TEST}

TEST \#9

CLENT: OAK RIOGE NAT LABS JOB\# 2107-T

DATE: SEPTEMBER 1, 1992

\begin{tabular}{ll|l|l|l}
\hline TIME: 1320 STARTUP & 1350 & 1430 & 1520
\end{tabular}

TEMPERATURES:

$T-1$ CONDENSERIN

T-2 CONDENSER OUT

$T-3$ EVAPORATOR OUT

T-4 EVAPORATORIN

T-5 DISTILLATE

T-6 VAPOA

T-7 CONC. RECYCLE

T-8 EVAPORATOR FEED

\begin{tabular}{l|l|l}
143 & 146 & 145 \\
144 & 147 & 146 \\
174 & 173 & 174 \\
177 & 175 & 176 \\
145 & 149 & 148 \\
152 & 153 & 153 \\
161 & 164 & 164 \\
154 & 161 & 161
\end{tabular}

FLOWS:

605 FEED (GPH)

COOLING WATER (GPH)

\begin{tabular}{l|l|l|}
30 & 30 & 30 \\
300 & 180 & 60
\end{tabular}

PRESSURES:

P1 DISTILATE PUMP

P2 COOUNG PUMP

P3 HEATING PUMP

C1 VACUUM

C2 CONC. PUMP

\begin{tabular}{|c|c|c|}
\hline$P$ & 35 & \\
\hline$P$ & 49 & 13 \\
& 20.5 & \\
& 2 &
\end{tabular}

35
21
13
20.5
2

35
19
13
20.5
2

TOTAL AMPS

VOLTAGE

HOUR METER READING

VOLUME CHECK

407 CONDUCTNITY $\mu s / \mathrm{cm}$

SAMPLE

DISTILATEPH

CONCENTRATE $\mathrm{pH}$

\begin{tabular}{|l|l|l|l|} 
& & & \\
& & & \\
\hline 2.8 & 2.2 & 2.4 & \\
\hline 8.7 & 8.8 & 8.2 & \\
\hline 8.5 & 8.4 & 8.4 &
\end{tabular}

NOTES:

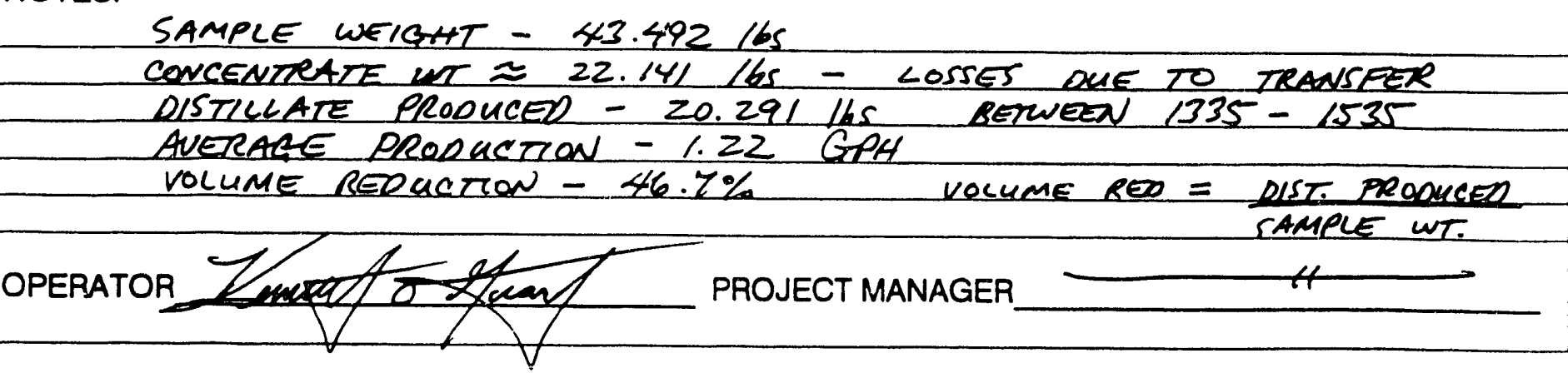

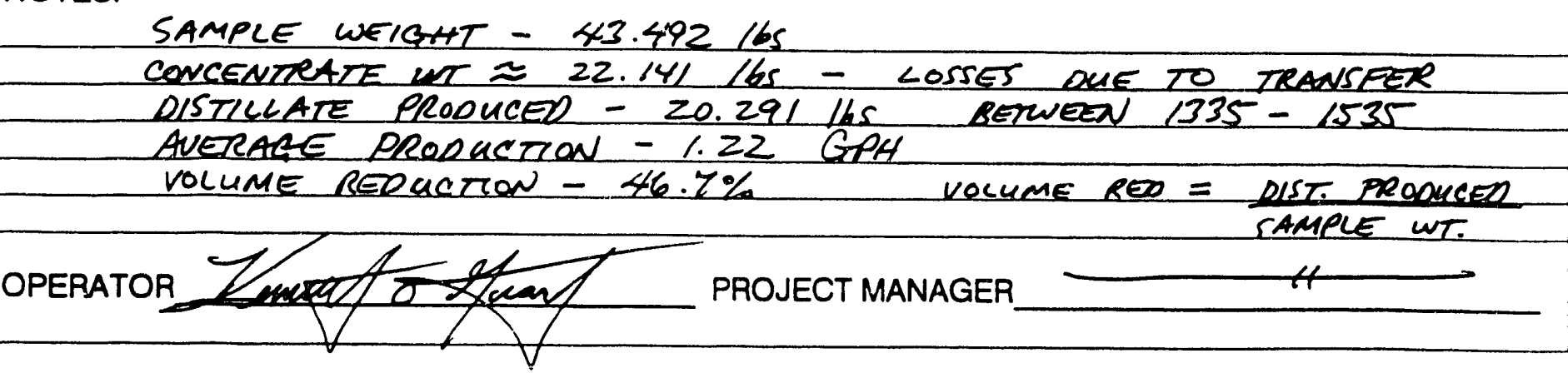

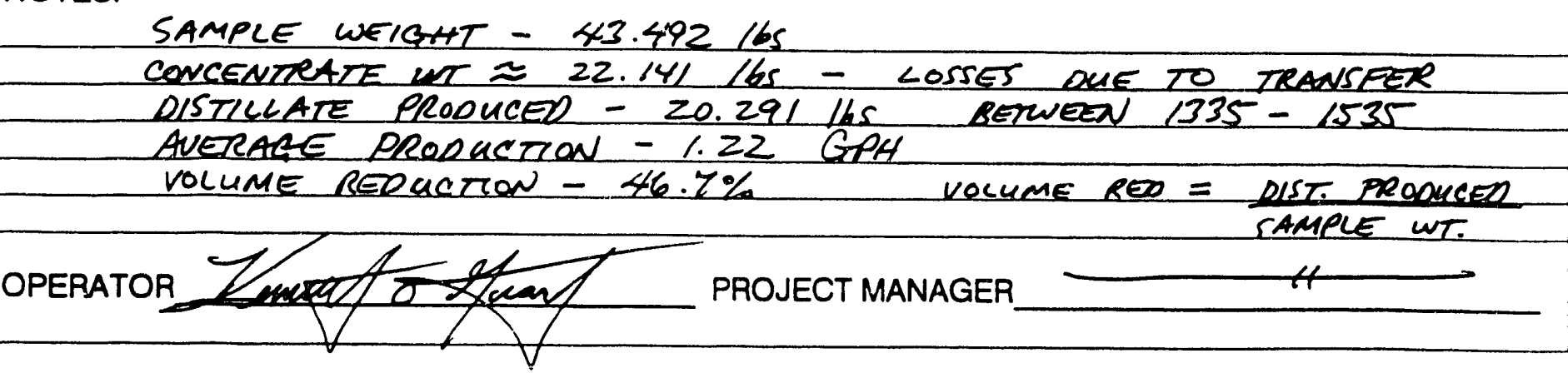

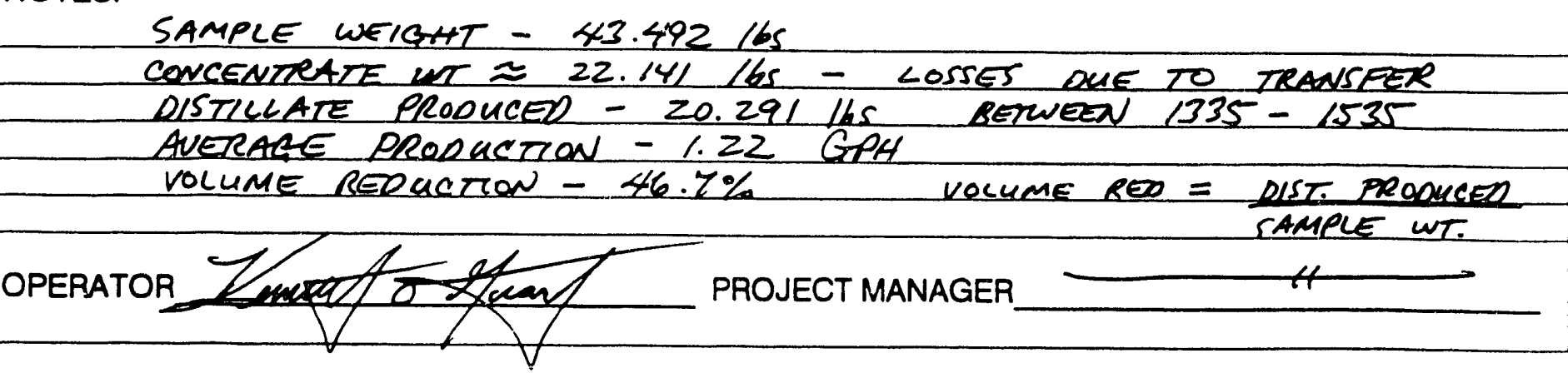

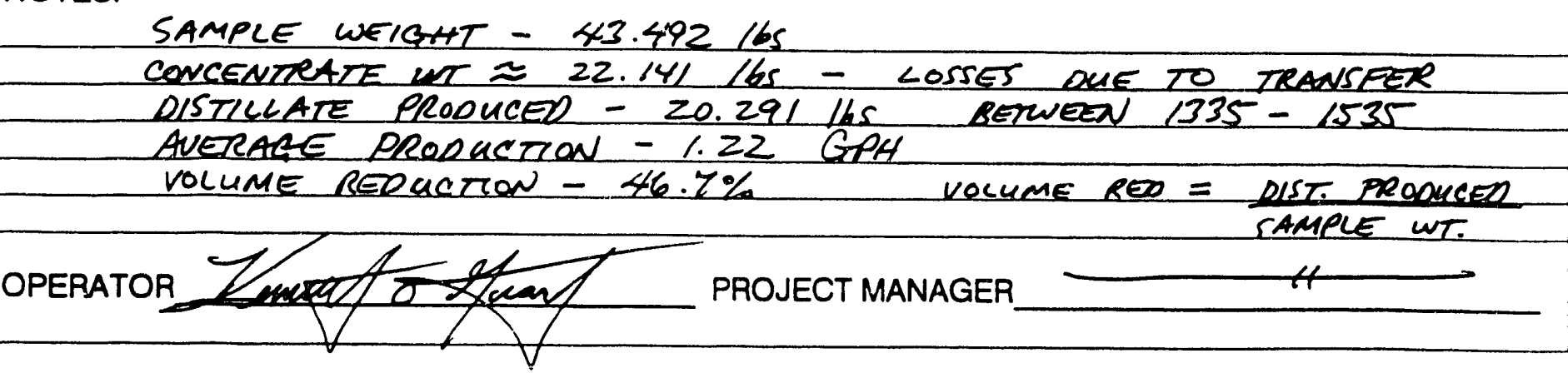

* w-28 surrogate

200 EAST GOVERNMENT STREET • SUITE 130 • PENSACOLA, FL 32501 • (TEL) 904/434-5088 • (FAX) 904/438-2040 


\section{APPENDIX B}

LETTTERS OF CORRESPONDENCE 
April 28, 1992

Mr. Vic Fowler

Oak Ridge National Laboratory

Bldg. 3017

P. O. Box 2008

Oak Ridge, TN 37831-6342

REF: Proposal 920429-080000-ORNL

Proposal for a Pilot Test

Dear Mr. Fowler:

We want to thank you and Joe Perona for visiting the LJCON facility on April 16. We enjoyed having you and always welcome the opportunity to show off our equipment to people who can appreciate it.

In response to your request to run extended surrogate test solutions at UCON's facility to study scaling tendencies, we propose the following test schedule and variables. Accurate weight measurement of the tube bundle will be made at the start and end of each test. As we discussed during our meeting. LICON will record all operating data temperatures and pressures and monitor the following six control factors.

\section{Foaming}

Is antifoam required? If so, how much? What type? We will test 3 different antifoams if needed.

2. Circulation Rate (Recirc to evaporator)

We will vary the feed rate to the evaporator from $5 \mathrm{GPH}, 10 \mathrm{GPH}, 30 \mathrm{GPH}$ and 60 $\mathrm{GPH}$ and record the effects on scale, carry over and concentration ratios.

3. Temperatures \& Pressures

Temperatures and pressures (vacuum) will be changed from a maximum of $26^{\prime \prime} \mathrm{Hg}$ up to $17^{\prime \prime} \mathrm{Hg}$ in approx. $3^{\prime \prime ~} \mathrm{Hg}$ increments. 


\section{Concentration ratio}

Varying degrees of concentration ratios will be plotted at $85,90,95$ and maximum achievable percent volume reduction. These can be compared with chemical analytical data for which we will send you samples to analyze. We have Hach test kit capability only, but we can analyze for 1-3 chemicals.

5. $\underline{\mathrm{pH}}$

$\mathrm{pH}$ will be adjusted from $6.5,7.5,10$ and 13 and compared with scaling, foaming and DF results.

6. Vapor Velocities

Vapor velocities through the mesh and in the vapor uptakes will be calculated for each condition.

A total of four tests will be conducted and run for 15 hours (each), under each set of operating parameters; for example test 1 will be at feed 5 GPH (2 GPH over evaporation rate) $26^{\prime \prime} \mathrm{Hg}, 85 \%$ concentration, pH 13. Test 2 will be at feed $10 \mathrm{GPH}, 24^{\prime \prime} \mathrm{Hg}, 90 \%$ concentration, pH 10. Similarly for tests 3 and 4 . Note, these parameters may be changed and noted as such if field observations and test results warrant it. Following each test, the tube bundle will be weighed and the equipment cleaned. The results will be turned in to an engineer for evaluation and inclusion into a final report. Rates for LICON technicians and engineers are printed at $\$ 550$ per day for technicians and $\$ 650$ per day for engineers (copy enclosed). Rental use for the equipment is $\$ 200$ per day. 
The price does not include the purchase of chemicals. When the exact surrogate solution is decided upon, LCON can purchase the chemicals or ORNL may purchase the chemicals and forward them to LCON. All final concentrate will be shipped back to ORNL for disposal. All solutions will be mixed using distillate water as evaporated from city water using a LUCON evaporator. After review of this data similar tests may be warranted to further expand upon the data being collected.

If you have any questions, please feel free to call either Bob McElroy or myself.

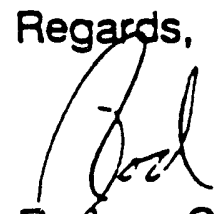

Aodney C. Williamson

Vice President, Sales

cc: J. Campbell-Service Manager
B. McElroy-Plant Manager

REF: Rodney $\backslash 0300.101$ 
To: Vic Fowler

Oak Ridge National Laboratory

CC: Robert MCElroy

Rodney Williamson

John Campbel1

From: Ken Grant

Date: July 13,1992

During a meeting between Bob McElroy, Johnny Campbell, and myself, the following strategy for testing surrogate samples $W-24$ and $W-28$ were tentatively agreed upon:

I. Each surrogate solution will undergo 5 separate tests.

II. Each Test will occur at a specified saturation temperature along with it's corresponding saturation pressure.

III. During the course of each testing period, data will be collected for foaming characteristics, concentration ratios, and vapor velocities.

IV. Foaming will be controlled by the addition of anti-foam or $\mathrm{pH}$ adjustment. All data concerning these adjustments will be recorded.

v. Concentration ratios will be observed and recorded for each of the separate tests.

VI. Scaling tendencies and amounts for each test are to be recorded.

Based on the levels of sodium Nitrate within the surrogate solution, we initially estimate our reduction capability to be $2: 1$. 


\title{
APPENDIX C
}

\author{
LICON, InC. \\ STANDARD SAMPLE TEST PROCEDURE
}




\section{PILOT TESTING STANDARD PROCEDURE}

1. Written or faxed copy of Purchase Order covering all costs including pilot test, shipping etc.

2. Chemical analysis or customer provided description of the sample composition.

3. Knowledge of personal and equipment hazards associated with each waste water sample.

4. Customer Requirements of the Test Results:

a. Quick turn-around especially on biologically active samples.

b. Lab analysis on request and prior notice.

c. Return of all concentrate volume and distillate samples collected during pilot test to the customer.

d. Written report and data sheet sent to the customer ASAP.

5. Test Procedure:

a. Start machine on clean water to establish proper operation.

b. Obtain representative feed sample for LICON records by mixing and shaking sample containers.

c. Drain clean water from concentrate tank and fill with test sample.

d. Record $\mathrm{pH}$ and conductivity of representative sample.

e. Perform "shake" test to determine foaming characteristics. Add appropriate defoamer amount and repeat shake test. Record all findings including type of antifoam most effective.

f. Start processing of sample in pilot unit.

9. No discharge of any liquid including distillate product until determined nonhazardous.

h. Observe and record phase changes during "heat-up" phase, especially foaming and distillate quality trends.

i. Record data and collect distillate samples every 30 minutes detailing any changes and volume reduction.

j. $\quad$ Process as far as volume will allow for maximum reduction ratio.

k. Collect all concentrate from tank bottom and all piping into sample containers. 
1. Inspect for heat exchanger scaling, if present pull out hox for full examination. Record amount, hardness, texture and color, retain large sample.

m. Notation of any and all damage to test equipment resulting from a test solution.

n. Complete flushing and cleaning of the pilot test unit and other equipment used in test period.

6. LICON Requirements:

a. Retainment of $250 \mathrm{ml}$ of feed, final concentrate and final distillate samples for LICON's records.

b. Original data sheet and copy of report.

c. Copies of the above sent to appropriate sales staff.

d. Proper packaging of test samples for shipment.

e. Prompt invoicing of pilot test, shipping costs, etc. 


\section{APPENDIX D}

\section{SUPERNATE COMPOSITIONS}




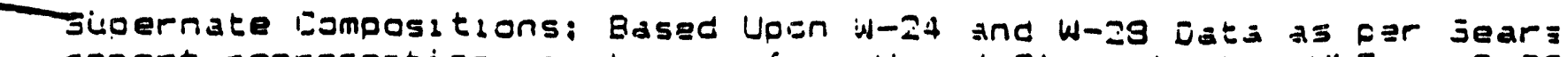
-iport representing worst case for $p H$ and $S i$ content. $: L F .=-\exists-92$

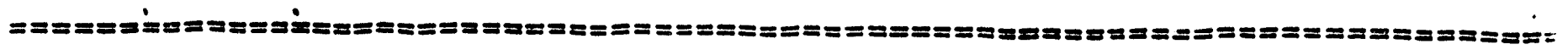

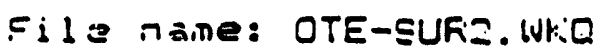

' $24=24=28$

Eamponerit.

इupernate
(gil) moies/L Supernate

\begin{tabular}{|c|c|c|c|c|}
\hline $\begin{array}{l}\text { NaNOS } \\
\text { KNOI }\end{array}$ & $\begin{array}{r}.59 .90 \\
20.519\end{array}$ & $\begin{array}{l}4.55 \\
0 .=0\end{array}$ & $\begin{array}{l}5 \overline{54.55} \\
66.70\end{array}$ & $\begin{array}{l}4.17 \\
19.56:-\end{array}$ \\
\hline NaZCOI & 15.90 & 0.15 & 1.136 & 9.01 \\
\hline NaCl & 4.27 & $\because 07$ & 4.09 & 1.2 .67 \\
\hline $\mathrm{NaOH}$ & D. ̇́s & $0.0=$ & 0.05 & 0.0 \\
\hline Ca (NOE) I*4HEO & 1.0 .5 & 0.00 & $47 \cdot 2=$ & $0.20 .$. \\
\hline MgCl 2*6H=ם & $\because .101$ & 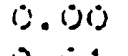 & $1=5$ & . \\
\hline NaZSIOS*THEO & $2.4 \bar{\Xi}$ & 1). $: 1$ & (i). & $0.01 \%$ \\
\hline pHi & $13.1 \%$ & & $\div .19$ & \\
\hline
\end{tabular}




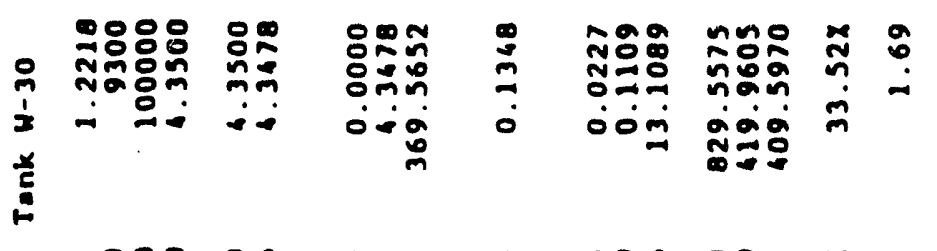

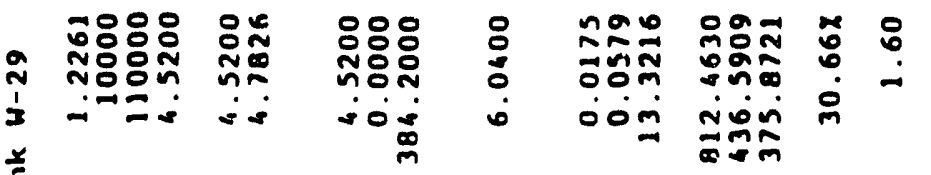

है

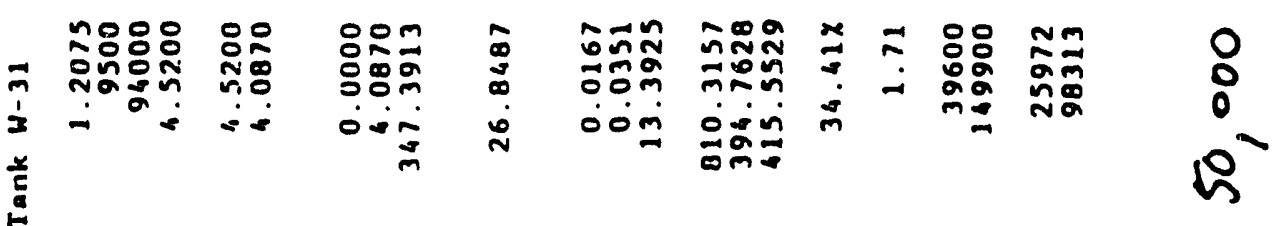

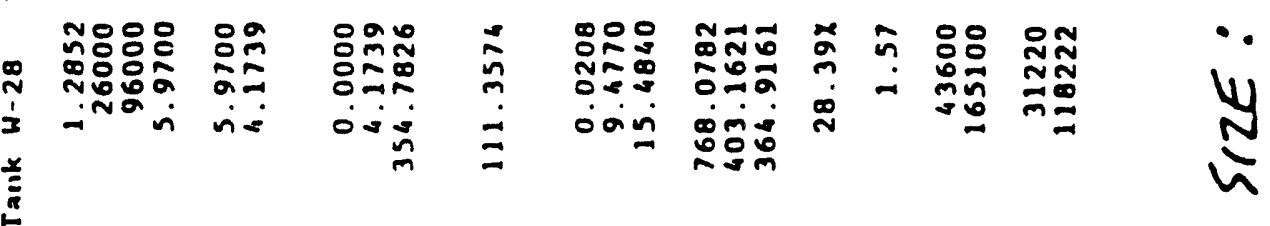

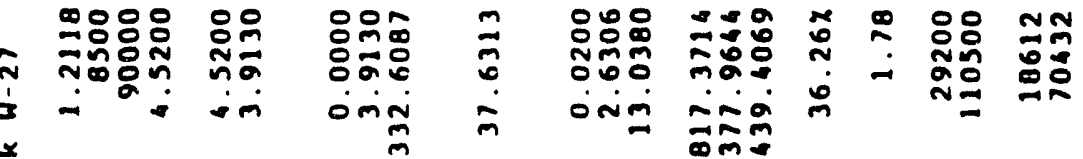

है

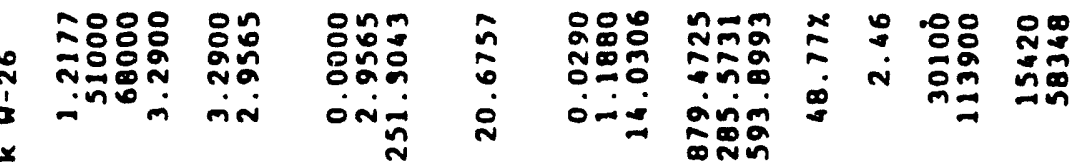

$\frac{\sqrt{3}}{4}$

$\stackrel{5}{E}$

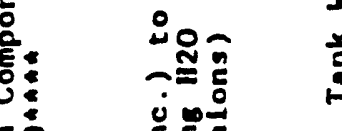

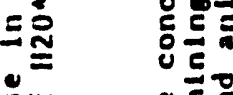

造

范

z

-

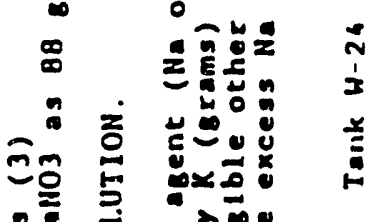

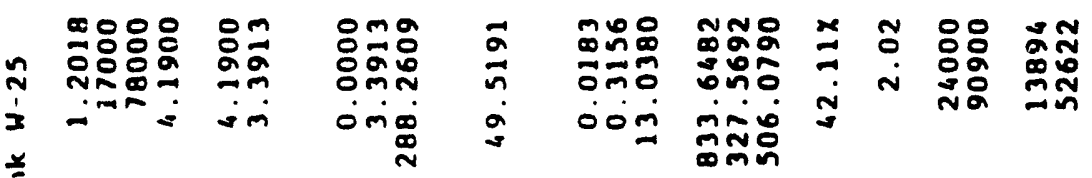

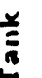

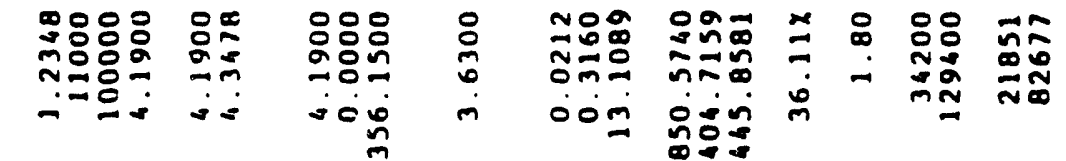
西

政

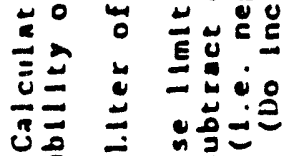

产

舟

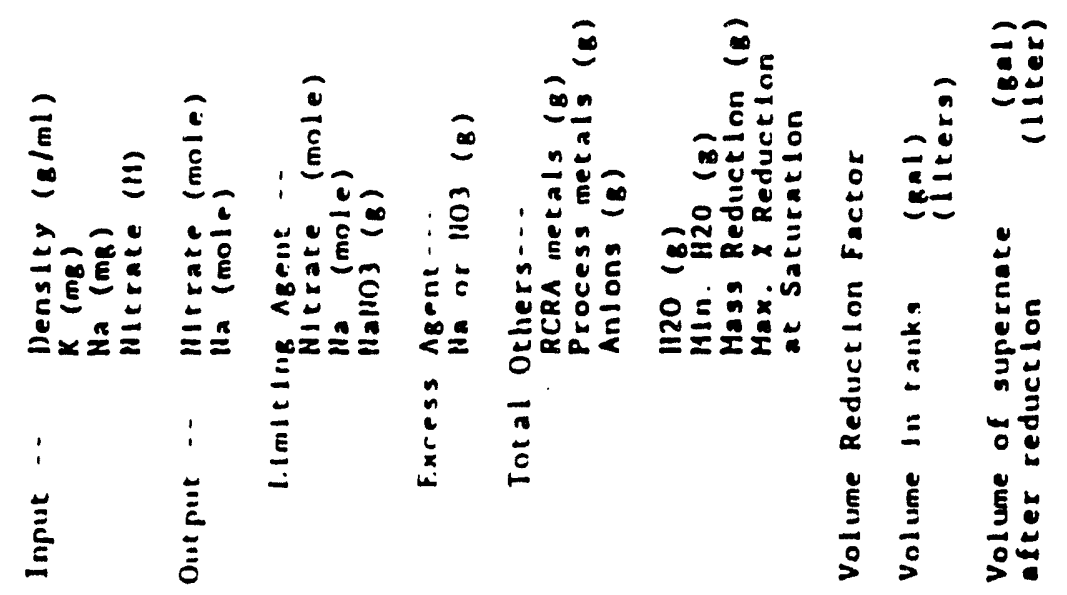




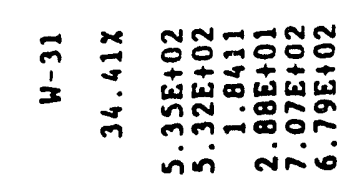

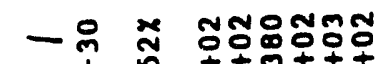

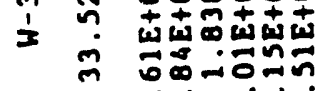
ini äin

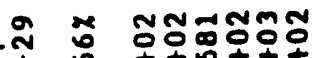

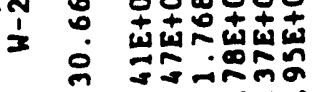
ini ini

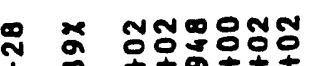

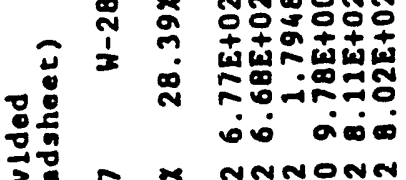

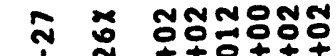

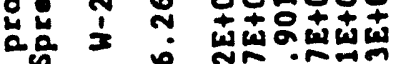

당.

눈

É

告。

दू

ᄃำ

:

ธิพ

르 ๘

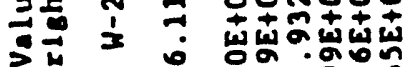

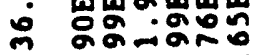
ini vimin
우음ㅇㅇ

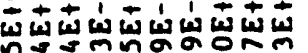

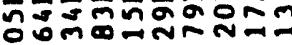

ivinianinimiñ

융윰ㅇㅇㅇ

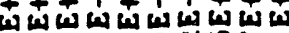

ดีกำธำกำด

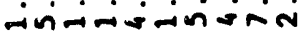

6으음ㅇㅇㅇ

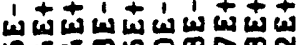

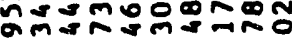

Oiñinimivinion

유읃ㅇㅇㅇㅇㅠ

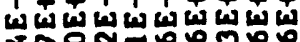

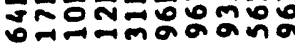

anionininino-

요융ㅇㅇㅁㅇㅇㅇㅠ

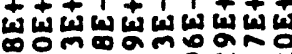

$0 \infty \rightarrow$

unomannimin

웅으뭉요

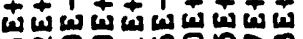

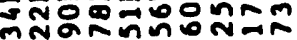

Niniominasin

ㅇํㅇ유유유유

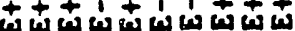

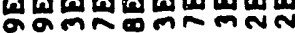
mnonma

-ioñinainiman

응ํํ유융

$+\downarrow 11+11+\$$

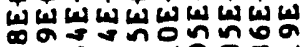

orñoतaom-

vivisisiñan

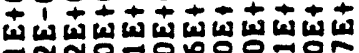

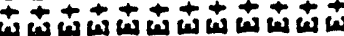

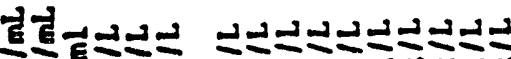 EE⿱}

ถธำธำำดัดธอง

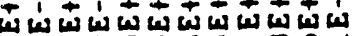

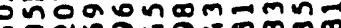

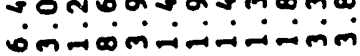

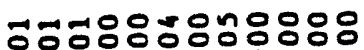

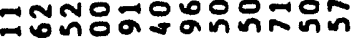

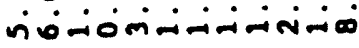

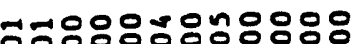
$+1+t+1+t+1+t$

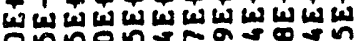

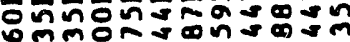
Noboma-ñNa

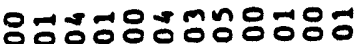

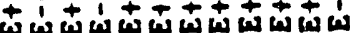

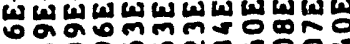
NoOaboNm=00? as-nmminataim웅ํํㅇํㅇㅇํㅇํㅇำ

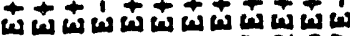

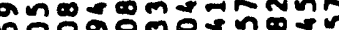
-i-jiñini-

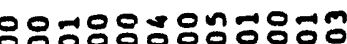

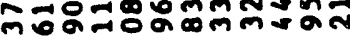
onimivióniñin 용융ㅇㅇㅇํㅇํํ융 $+++1++++++4$ w

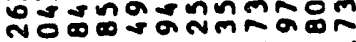
n-isiniñminํํำธํํำกำำ

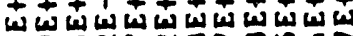

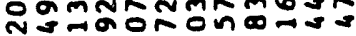
rindosiñinama

Nํㅇํำ

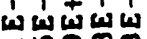
चooㅇaㅁ - inomín Nㅜㅇ종 웅ㅇ

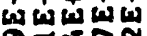
ลีที丶万ळ iminis Nํㅇํำ 1 t任

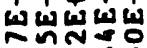
تñnón imonis ธีํํํํำ

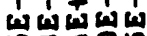

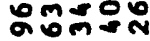
iminin TNONN 웅요 山心 =ㅇำ 坵禹 ㄷํㅇํำ

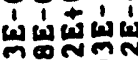
กू๊ํำ -inoธํํㅇ중ํํ 1́t的市

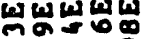
लूज्तन

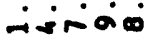

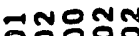
oo이

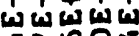
二ó율 $\therefore$

$\sum \Sigma \sum \Sigma \Sigma$ EЕEE

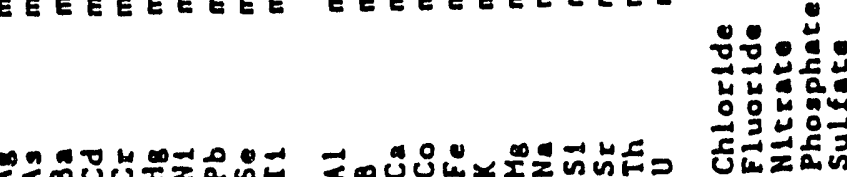

NกN

Ni⿱

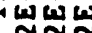

กัñ

สาก

MNN

mi

H 냉는

ลã

ind

-

i.

藏步

ลू०

คำ

-NNT

Ni

칭형닝

웅영

再-

NNNN

Ni⿱

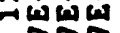

ทีทั丶

กंनं

ตำำ

Ni

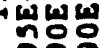

ดून

$\because$ mm

뭉ํำ

첨테

西示

जनञ

mili

$\rightarrow$ w wh

ที่กิ

ปก-

エエ厂$$
\Sigma
$$

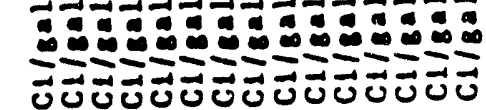

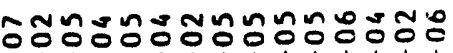

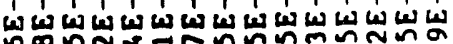

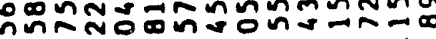

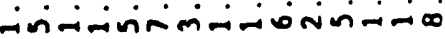

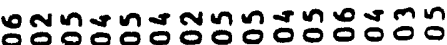
乡่

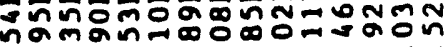

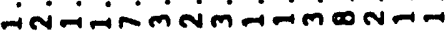
ํํㅇํํㅇํํㅇํㅇํํㅇํㅇํํํํㅇํㅇํํำ

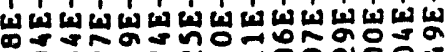

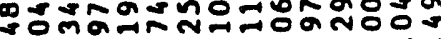
-iminaiñmiñinamin-

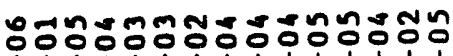

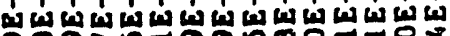

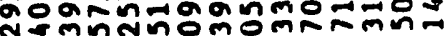

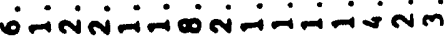
ำกำกำำกำกำำำ

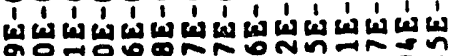

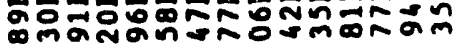

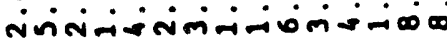

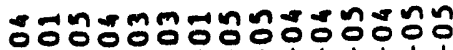

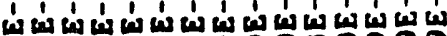

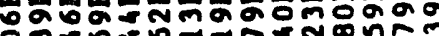
isNinisisinainion

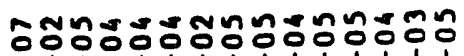

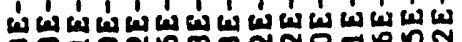

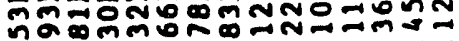

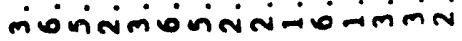

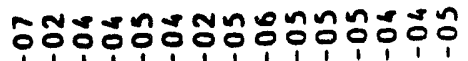

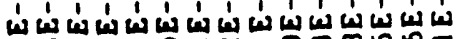

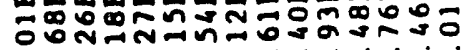

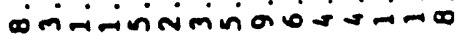

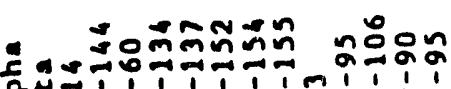

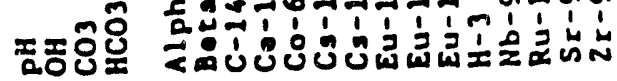




\section{APPENDIX E}

SAMPLE CALCULATIONS 


\section{PRODUCTION RATE}

$\mathrm{T} 1$ (Condenser In) $=87 \circ \mathrm{F}$

T2 (Condenser Out) $=121^{\circ} \mathrm{F}$

Cooling Water (GPH) $=50$

$$
\begin{aligned}
& P=M * C *(\text { Delta }-T)
\end{aligned}
$$

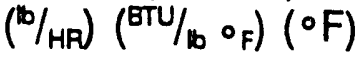

$$
\begin{aligned}
& M=\text { Cooling Water (GPH) } \\
& \mathrm{C}=1 \mathrm{BTU} / \mathrm{HO} \circ_{\mathrm{F}} \\
& \text { Delta-T }=(T-2-T-1) \circ F
\end{aligned}
$$

Test \# 1/W-28 / July 14, 1992 / 12:00

$\mathrm{T}-1=90 \circ \mathrm{F}$

$\mathrm{T}-2=92 \circ \mathrm{F}$

$M=60 \mathrm{GPH}$

$$
\begin{gathered}
P=(60 \mathrm{GAL} / \mathrm{H})(8.34 \mathrm{~b} / \mathrm{GAL})(1 \mathrm{BTU} / \mathrm{b} \circ \mathrm{F})(2 \circ \mathrm{F}) \\
P=1000.8 \mathrm{ETU} / \mathrm{HR}
\end{gathered}
$$

It requires 1,000 BTU's to produce $1 \mathrm{lb}$. of steam.

$$
P=1 \% / H A
$$




\section{VAPOR VELOCITY}

Test \# 2 / W-28 / July 15, 1992 / 14:25

$$
\text { PRODUCTION }=12.51 \% / \mathrm{HR}
$$

T6 (Vapor) $=154^{\circ} \mathrm{F}$

$$
\begin{aligned}
& V_{8}=88.52 \mathrm{Ft}^{3} / \mathrm{Lb} \quad \text { (Specific Volume) } \\
& \begin{array}{l}
\mathrm{Q}=V^{*} A \\
V=Q / A
\end{array} \\
& \begin{aligned}
Q & =\text { Volumetric Flow Data } \\
V & =\text { Velocity } \\
A & =\text { Cross-Sectional Area }
\end{aligned}
\end{aligned}
$$

3" SCH 80 CPVC

$\mathrm{OD}=3.5^{\prime \prime}$

Thickness $=0.3^{\prime \prime}$

ID = 2.9"

$A=(3.14)(\mathrm{Dl}, 14$

$A=0.0459 \mathrm{Ft}^{2}$

$$
\begin{gathered}
V=(12.51 \mathrm{Lb} / \mathrm{Hr})\left(88.52 \mathrm{Ft}^{3} / \mathrm{Lb}\right) / 0.046 \mathrm{Ft}^{2} \\
V=24,147 \mathrm{Ft} / \mathrm{Hr} \\
V=6.71 \mathrm{Ft} / \mathrm{Sec}
\end{gathered}
$$




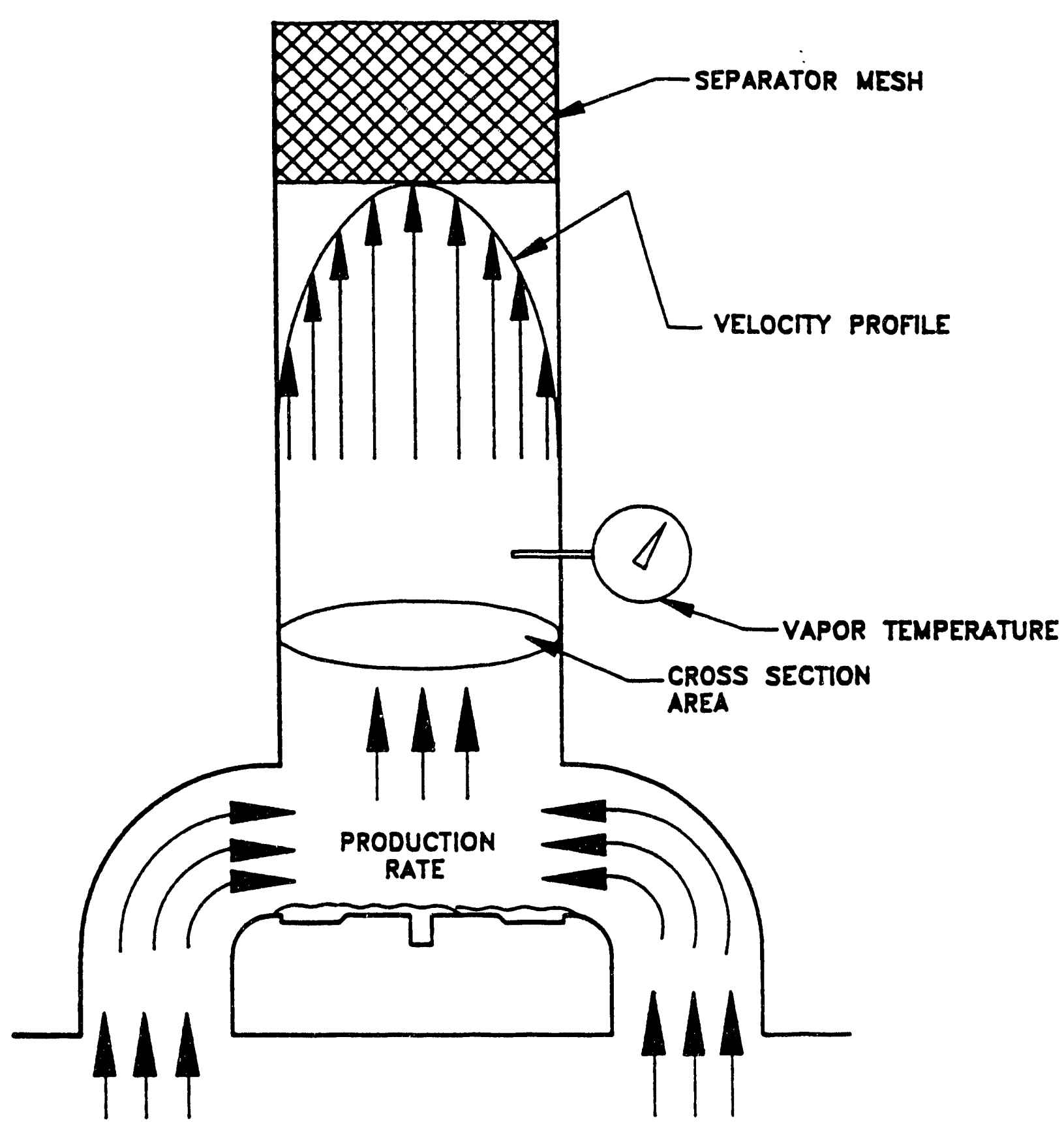

FIG. 1 VAPOR VELOCITY 
72

BOILING POINT ELEVATION

Test \# 1 / W-28 / July 14, 1992 / 12:00

$$
\begin{aligned}
& \mathrm{BPE}=(\mathrm{T} 7-\mathrm{T} 6)^{\circ} \mathrm{F} \\
& \mathrm{BPE}=\text { Boiling Point Elevation } \\
& \mathrm{T} 7=\text { Concentrate Recycle } \\
& \mathrm{T} 6=\text { Vapor } \\
& \mathrm{BPE}=116^{\circ} \mathrm{F} \cdot 112^{\circ} \mathrm{F} \\
& \mathrm{BPE}=4^{\circ} \mathrm{F}
\end{aligned}
$$




\section{APPENDIX F}

SCALE DEPOSITION 
The following report was supplied by LEPO Custom Manufacturing, Midland, Texas. From the information provided by PAI Corporation regarding the chemistry of tank W-24 (Appendix D - Volume Reduction Calculations) LEPO analyzed the possible formation of scale due to high silica presence. In order to accomplish the analysis, LEPO simulated the W-24 solution and applied sub-atmospheric evaporation conditions. The results of these conditions are documented on the following pages. It is to be understood that the results of this report are based on simulated parameters which were designed to best represent what actually exists at ORNL.

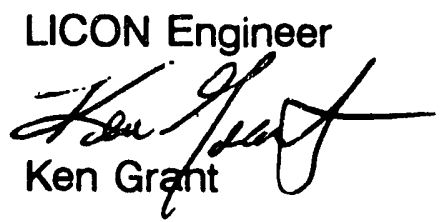


Ryznar attompted to quantify the relationship botween calcium carbonato saturation stato and scalo formation.

Ryenar stabllity index can be summarized as follows:

RSI \& Sialo tondency increases as the index decreases;

RSI, 7 calcium carbonate formation will probably not lead to a protective corrosion inhibitor filmi

RSI, 8 mild steel corrosion becomes a increasing problem.

Like the Lanyeller sacuration Index. The Ryznar Index Is applicable to lower TDS waters.

\section{SUMMARY OF ANALYSIS ANU RECOMMENDATIONS}

THE ORNL PROJECT WATER SAMPLE W-24, REDUCED FLUID, SHOWS ONLY TWO MOLECULES THAT CAN CAUSE PROBLEMS, BRUCITE AND HYDROXYAPATITE.

BRUCITE, A PRECURSOR TO MAGNESIUM SILICATE MAY BE CONTROLLEO BY AOJUSTING THE HH TO $12.2,00.0$ +0.3 WITH HYDROCHLORIC ACID ( $H C L)$. THIS ACTION MOVES THE BRUCITE INTO THE PERMANENT SOLUBLE RANGE WITH TEMPERATURE RANGING FROM 70 DEG F TO 180 DEG F.

HYOROXYAPATIIE, GECOMES DOMINANT AT PH'S OVER 12.4. IF THE PH IS AUSUSTED FOR BRUCIIE. THIS ACTION WILL ALSO CONTROL THE FORMATION OF HYOROXYAPAIL IL SCALING TENOENCIES.

AT THIS STAGE OF THE SIUUY I SEE NO NEED FOR A SCALE INHIBITOR OR SCALE REMOVER.

PLEASE CALL IF HAVE MINT QUESTIOIYS.

RESPECTFULLY YOURS.

AL KULIK 
DOWnHO1E SAT(tTR)

BURFACE WAI'EK CHEMIBTRY INPUT

\begin{tabular}{|c|c|c|c|c|}
\hline ZICON & ORNI & $\begin{array}{l}S \\
R\end{array}$ & 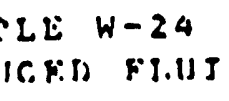 & \\
\hline po & $\begin{array}{l}\text { DaEd } 8 \\
\text { ID } 1\end{array}$ & thes & & at 2219 \\
\hline
\end{tabular}

CATIONS

\begin{tabular}{|c|c|}
\hline 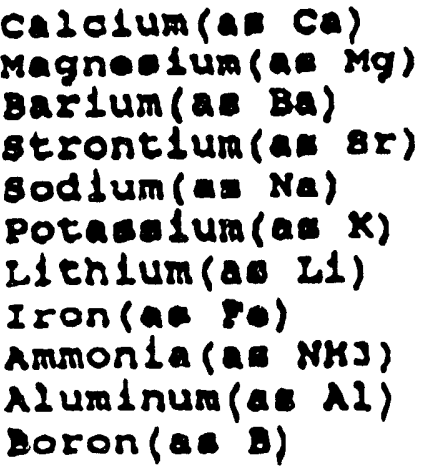 & $\begin{array}{r}21.30 \\
2.03 \\
0.30 \\
1.16 \\
257028 \\
17200 \\
0.00 \\
4.07 \\
0.00 \\
72.00 \\
1.50\end{array}$ \\
\hline
\end{tabular}

\section{ANIONS}

cnlorlde (as Cl) sulfare(as s04) Bloarbonate (as HCOJ) Carbonate (as coj) 81110a (as 81) Phosprate (as PO4) H2S (a. H28) Iluortde (ae F) Nitrate (as Nos)

4042

6.50 957.00

24100

383.00

7.80

0.00

0.77

406,70

\section{PARAMETtaRe}

$\begin{array}{lr}\text { PH } & 13.70 \\ \text { ramparature (Dag F) } & 180.00 \\ \text { Caloulatad T.D.8. } & 482600\end{array}$

Prescure (Atm.)

$\mathrm{P}-\mathrm{CO2}$ (Ata)

Dano 1ty (9/ml)
0.31

0.00465

1.20

1.EPO: CUSTOM MFL. INC.

MIULAND, IEXAS

- 


LICUN OKNL SAMPLE W-24
REDUCEL FLUID

Repore Date: 0B-25-92 Bampled: OB-2B-02

Bampla ID: 0 at 2228

BATURATION LEVEL

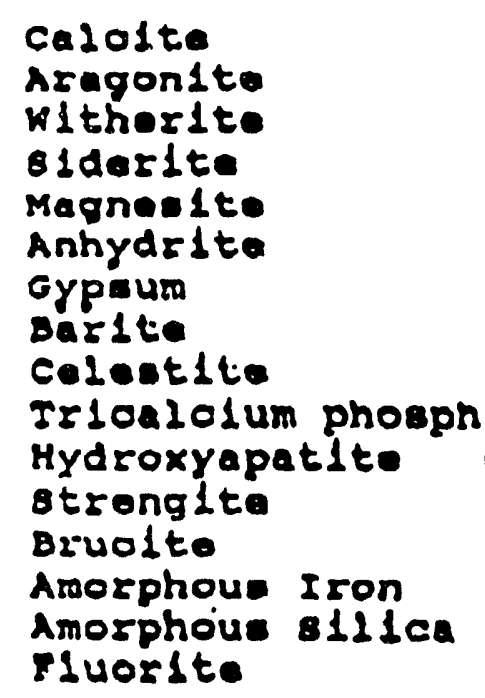

\section{COMMON INDICES}

Langel ler
Rysnar
puakor due
stlff-Davie
oddo-romeon
zarmon-skold

$-24.06$

24.06

$14.0 C$

$-14.08$

$-24.06$

99.0

Caso4 $2 \mathrm{H}^{2}$

$\square 0804$

82504

$\mathrm{Ca} 3(\mathrm{PO} 4) 2$

$\operatorname{Cas}(\mathrm{POA}) \mathrm{S}(\mathrm{OH})$

TEPOA*2H?O

$\mathrm{Mg}(\mathrm{OH}) 2$

$\mathrm{Ye}(\mathrm{OH}) 3$

8102

CaF2
$<0.001$

$<0.002$

$<0.002$

$<0.002$

$<0.001$

31.00

$<0.001$

70558

$<0.002$

$<0.002$

$<0.001$
BOUND IONS

calcium

Bar 1 ur

Carbonate

Phoophate

sulsate
TOTAL

FRE

9.42

0.42

0.00

6.58

5.42
$<0.00$
0.0
0.0
6.2
0.3




\section{Amorphous Silica Saturation Level}

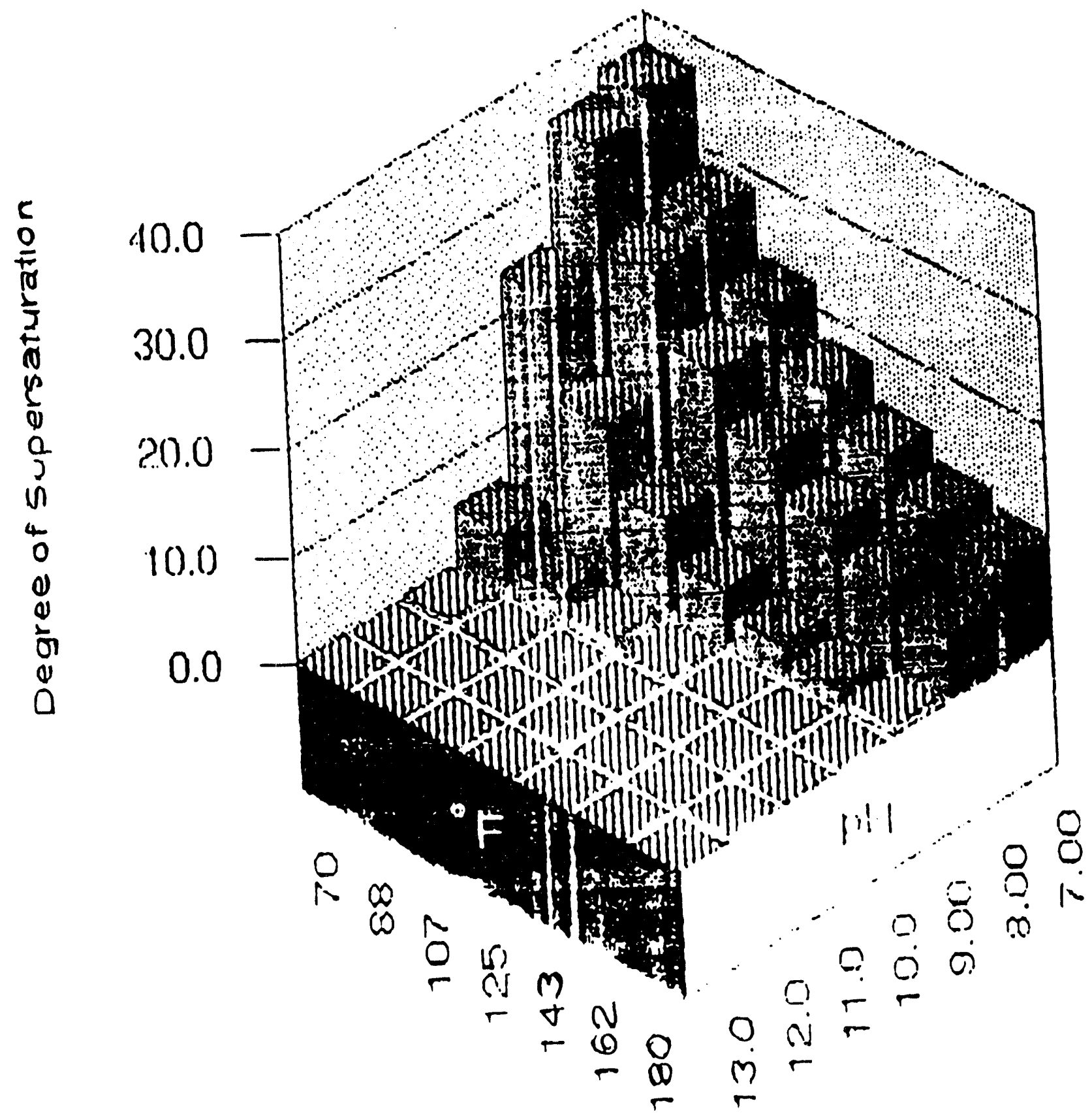




\section{Brucite Gaturation Level}

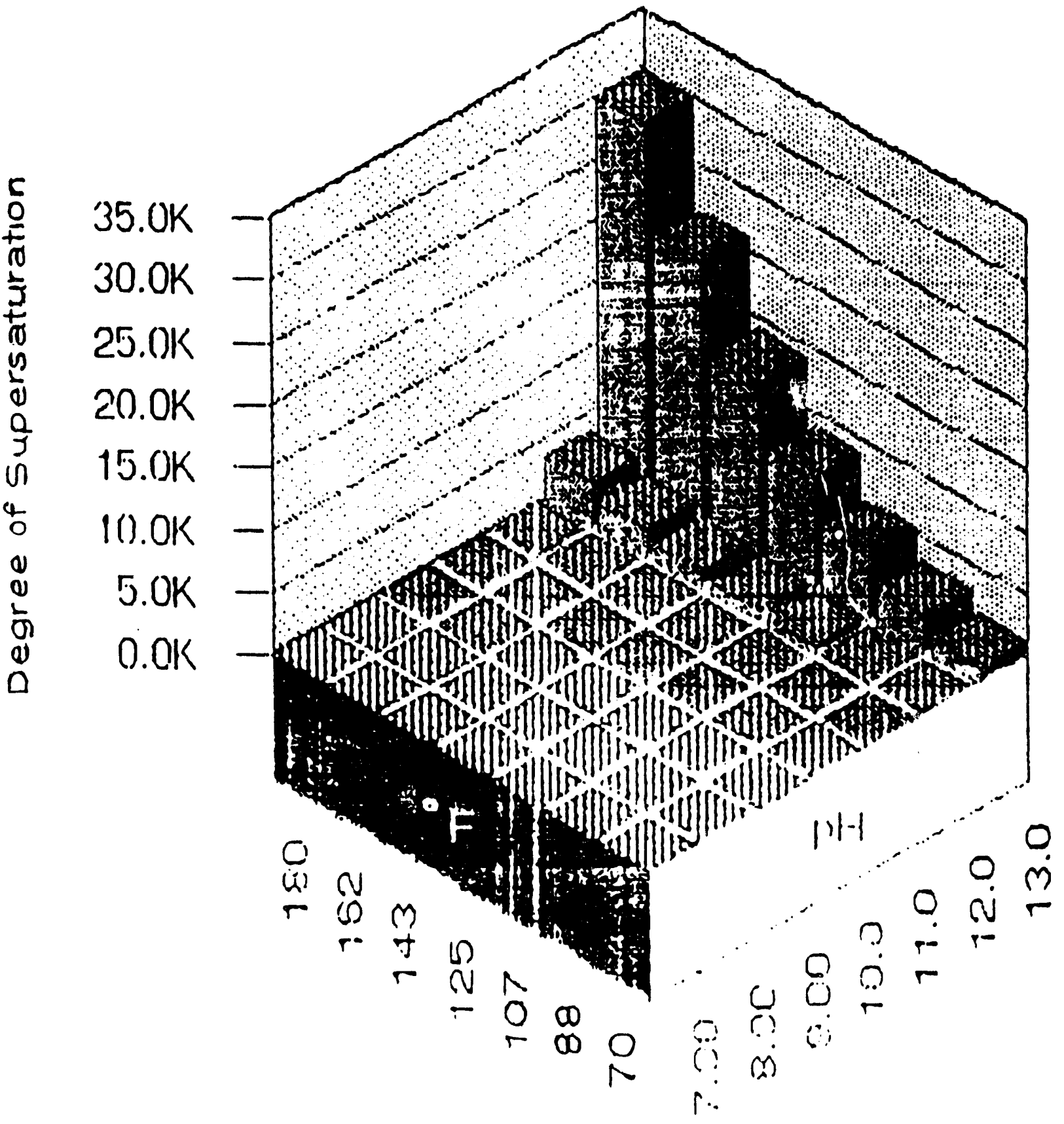




\section{Brucite Saturation Level}

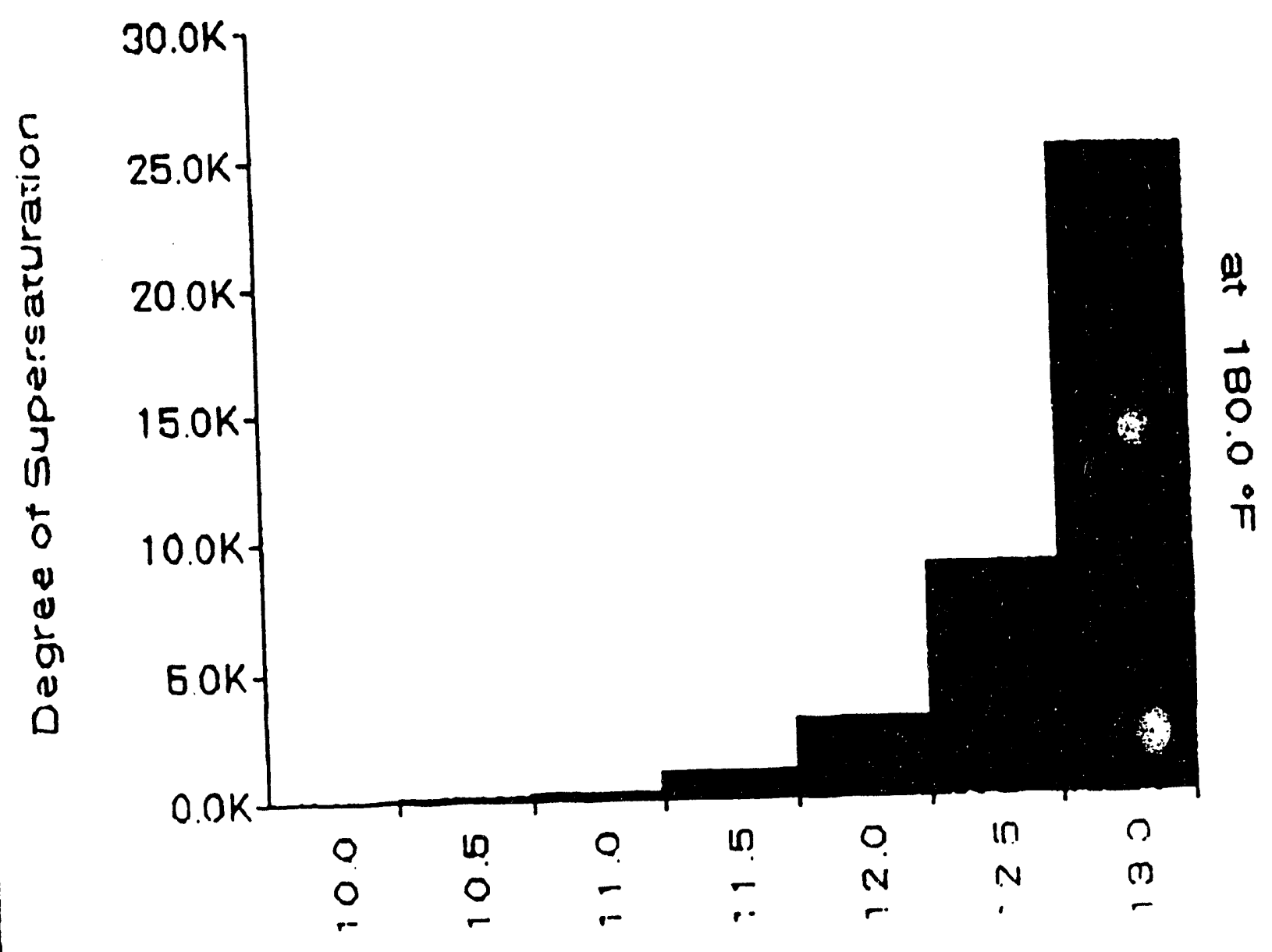

$\mathrm{pH}$ 


\section{APPENDIX G}

\section{FLOW DIAGRAM}




\begin{tabular}{|c|c|c|}
\hline \multicolumn{3}{|c|}{ NORMAL TEMPEF } \\
\hline$n 1$ & CONOENSER IN & $130-1357$ \\
\hline$\pi 2$ & condenser out & $135-140 \%$ \\
\hline$\pi \mathbf{3}$ & EVAPONATOR OUT & $180-180 \%$ \\
\hline$\pi 4$ & ENAPORATOR $n$ & $185-190 \%$ \\
\hline$\pi$ & Distmuate & $140-1467$ \\
\hline$\pi$ & VAPON & $150-155 r$ \\
\hline$\pi 7$ & CONCENTRATE RECrar & $180-180 \%$ \\
\hline
\end{tabular}

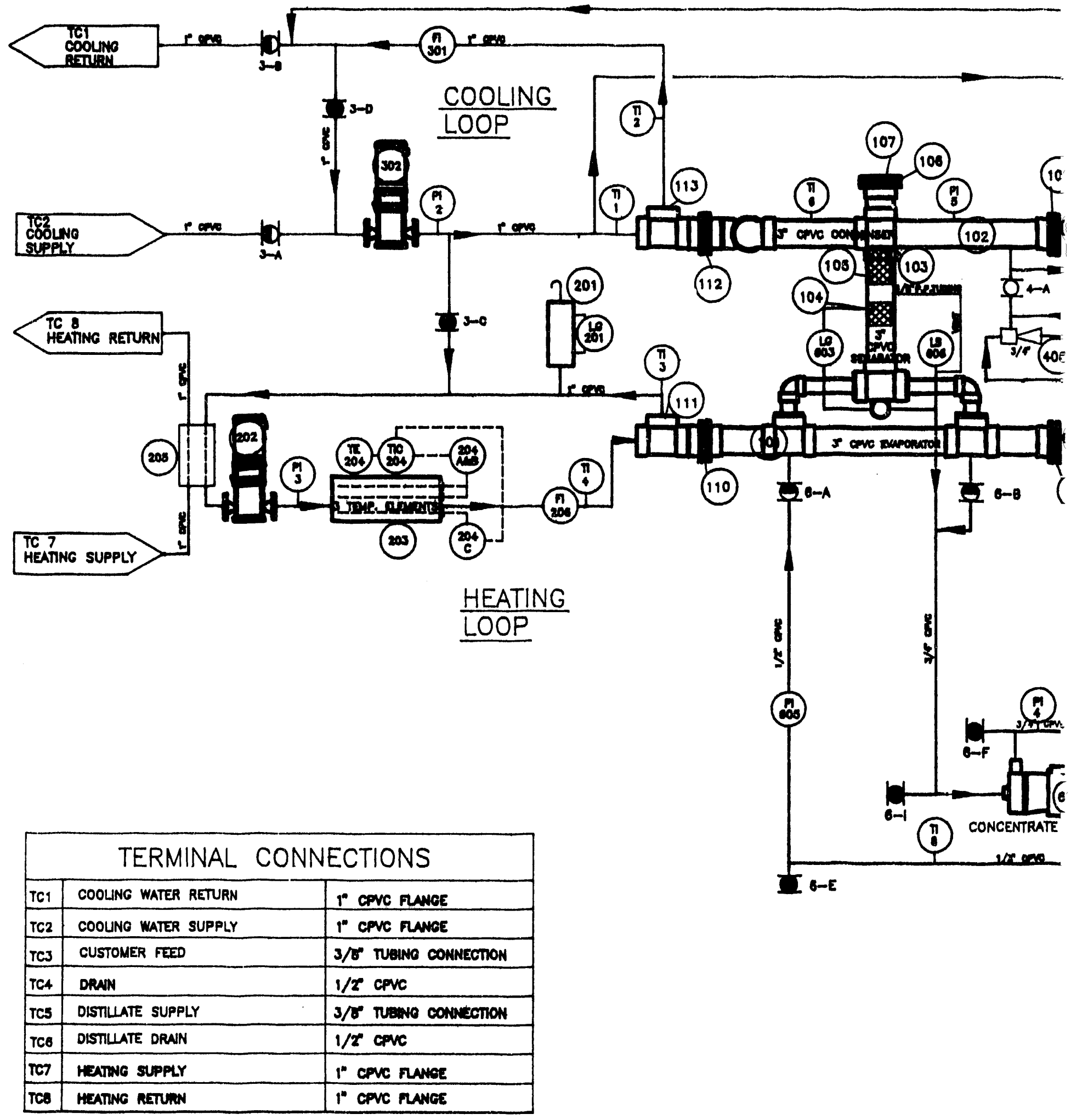


ATURES AND PRESSURES

\begin{tabular}{|c|c|c|}
\hline$\pi 0$ & EVAPORATOR FUED & $145-155 \%$ \\
\hline 91 & DISTILATE PUMP & $35-40$ palo \\
\hline $\mathrm{Pl}_{2}$ & COOLNA PUMP & 5-10 polg \\
\hline $\mathbf{M ~} 3$ & HEATNG PUMP & 5-10 polg \\
\hline H 4 & CONCENTRATE PUMP & 5 polo \\
\hline PI 8 & VACUUM & $28-28^{\prime \prime} \mathrm{Hg}$ \\
\hline PI 5 & Sell wares & \\
\hline
\end{tabular}

107

107) $T_{4-0}+-E$

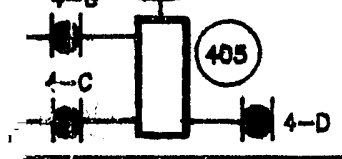

i

)

05)

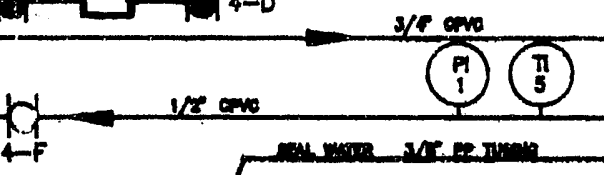

7)

)

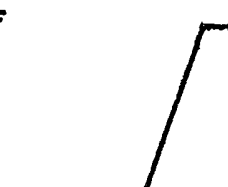

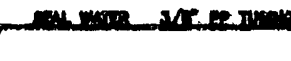

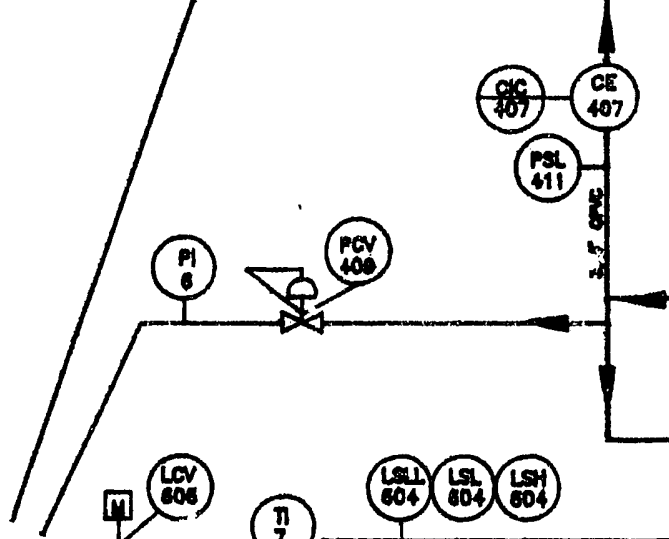

DISTILLATE

LOOP

403 (181)
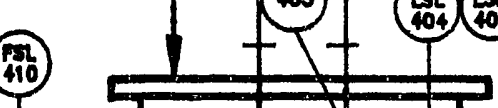

IStILLATE

TANK

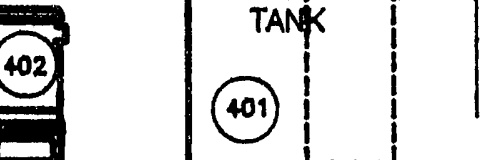

resing

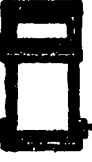

ram

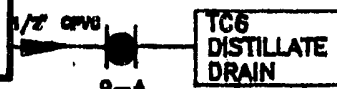

DISTLLL
DRAN

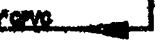

3/

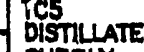

SUPELYY

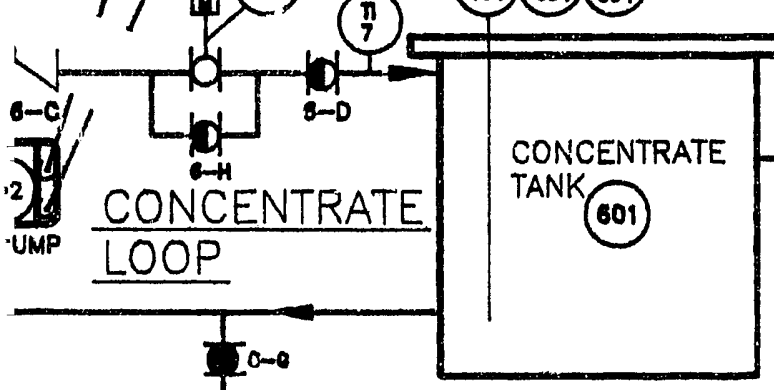

(5)
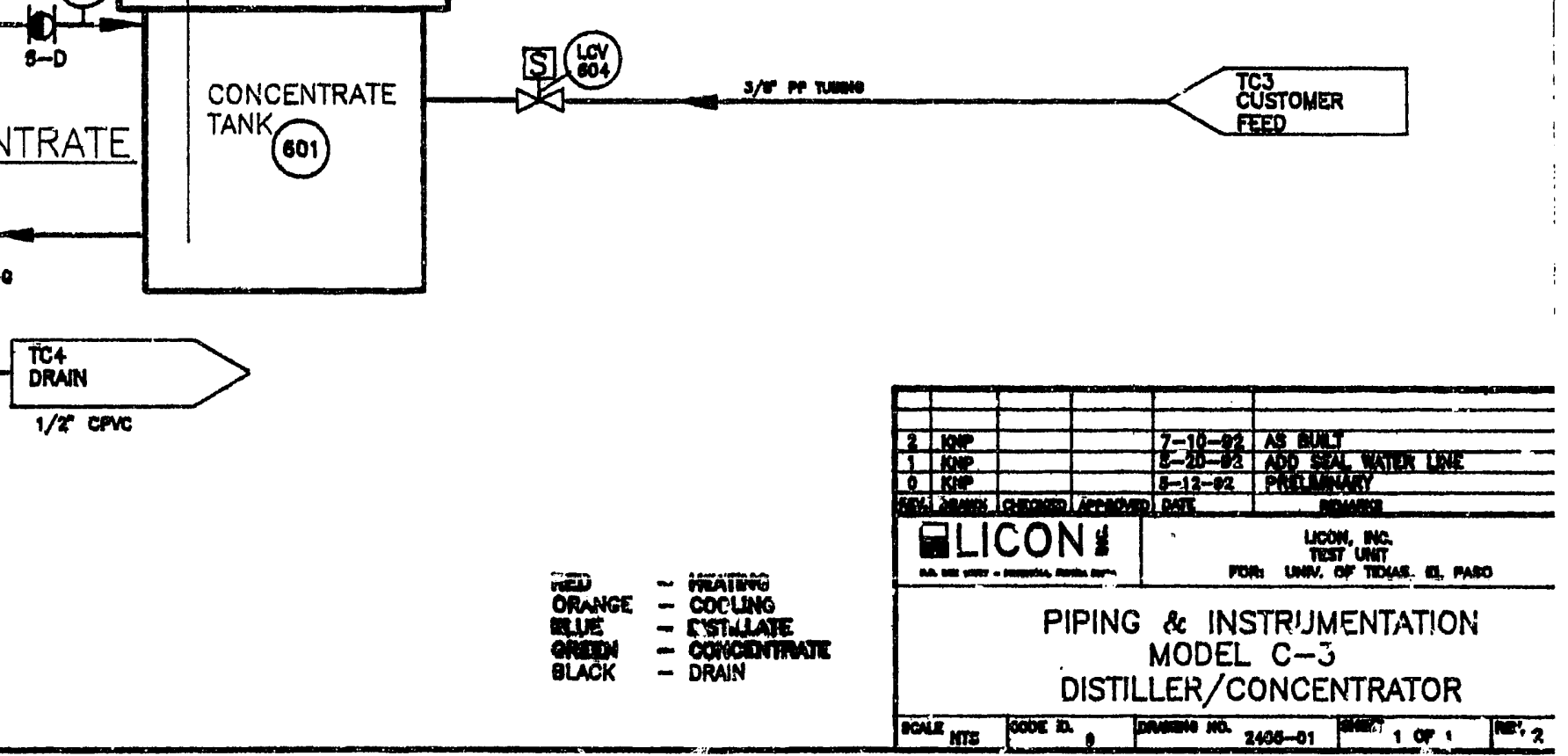

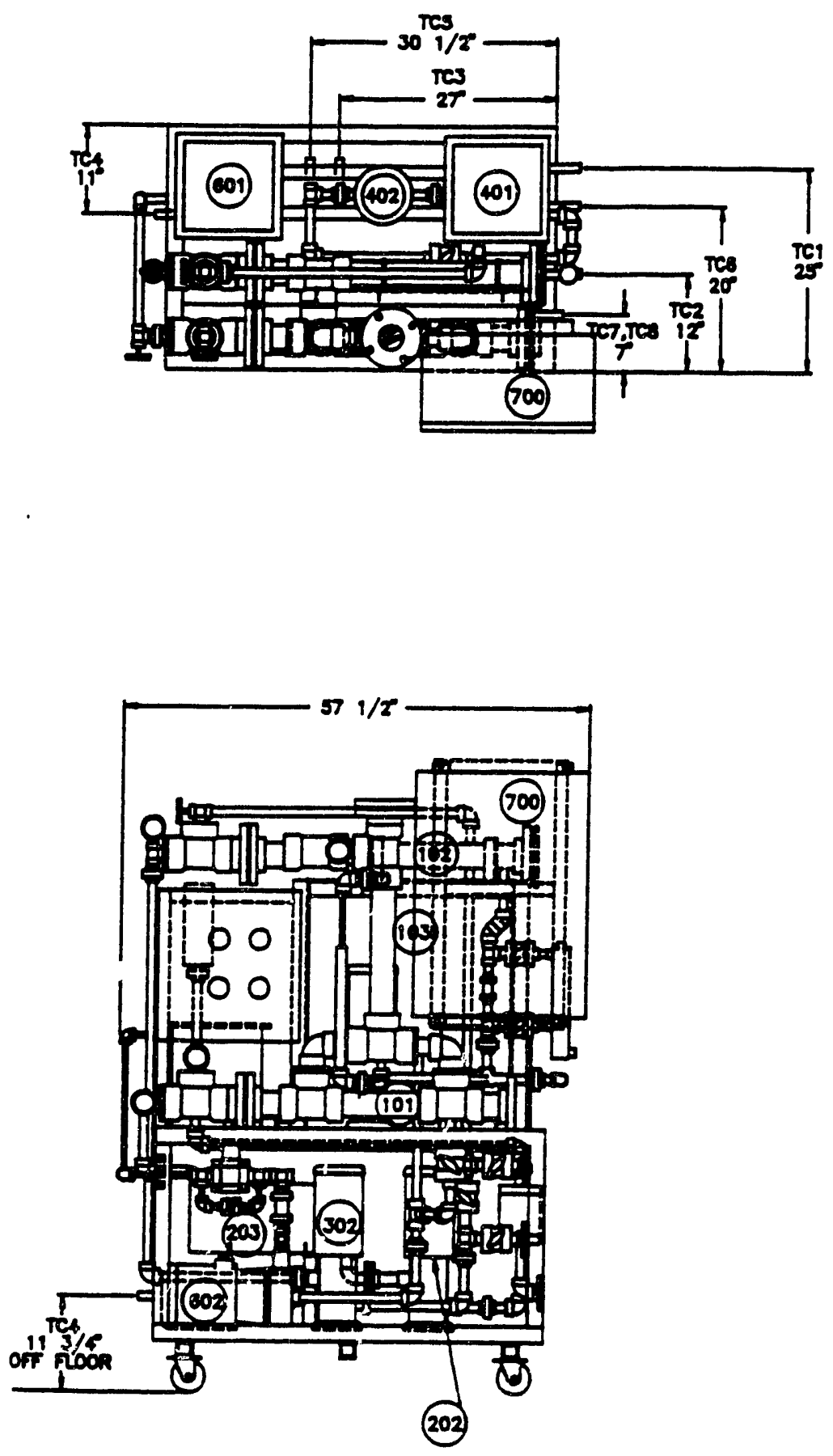

${ }^{5}$ 


\begin{tabular}{|c|c|c|}
\hline \multicolumn{3}{|c|}{ TERMINAL CONNECTIONS } \\
\hline$\sqrt{191}$ & $\operatorname{cosin}$ Rinnin & 50 \\
\hline TC2 & cooring sum & \\
\hline ITS & कs & 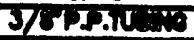 \\
\hline$\pi A_{4}$ & D.WI & $1 / \sqrt{2}$ \\
\hline F्ञ & 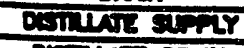 & $5 \sqrt{3 p t \pi}$ \\
\hline$\overline{T C O}$ & osulan owy & $1 / z$ cNe \\
\hline II & HATIS STintr & Tane \\
\hline TES & 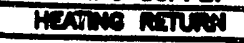 & $1+\cos$ \\
\hline
\end{tabular}

\begin{tabular}{|c|c|c|c|}
\hline \multicolumn{4}{|c|}{ MAJOR EQUIPMENT LIST } \\
\hline$\frac{101}{102}$ & Exponaso & Jave Thiakes & \\
\hline$\frac{102}{1003}$ & 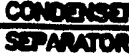 & $\frac{3 G N C}{3 a n c}$ & \\
\hline 202 & Hes mut & & \\
\hline 203 & $\mathrm{DT}=\mathrm{HWA}$ & & \\
\hline 200 & HXIT $X_{C A}$ & arean & \\
\hline 302 & $\cos \frac{1}{p}$ & 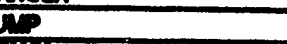 & \\
\hline$\frac{401}{462}$ & D. & & \\
\hline 661 & colinesills & $57 \mathrm{~W}$ & \\
\hline & $\frac{\operatorname{coscasin} x}{\operatorname{archoces}}$ & $\frac{p_{\text {powp }}}{\text { PNy }}$ & \\
\hline
\end{tabular}

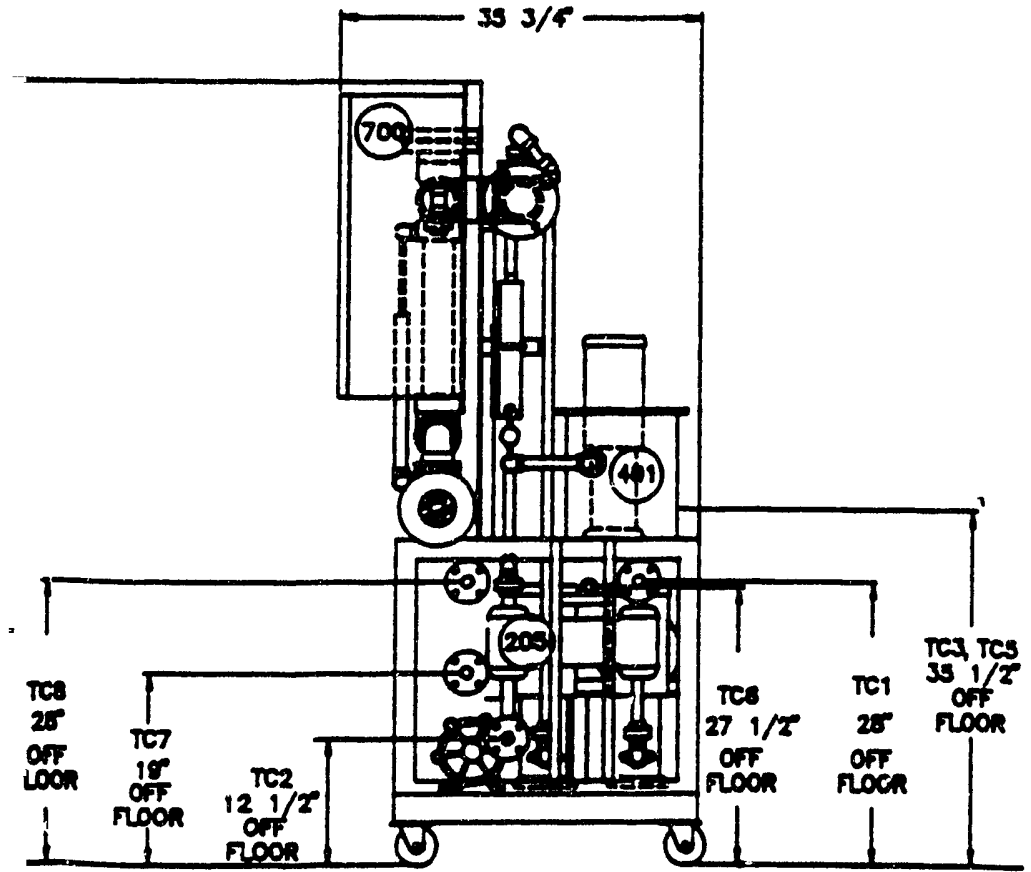

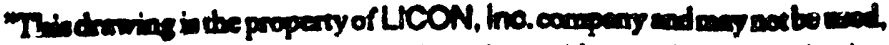

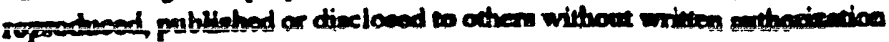

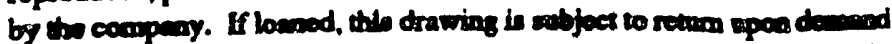

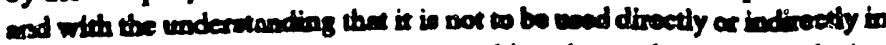

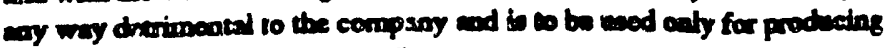
hem en arder for the compeny."

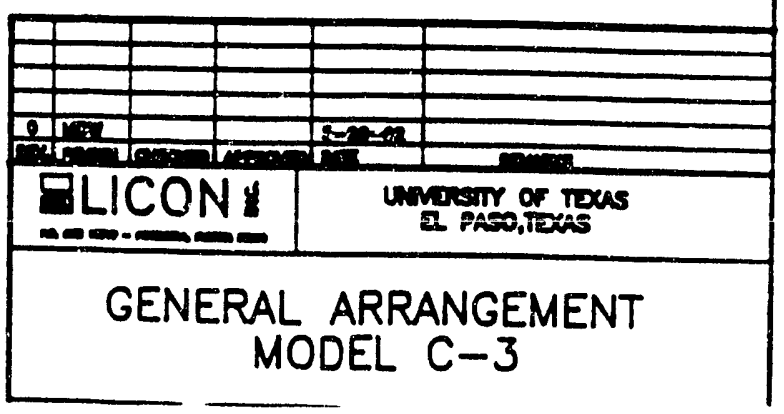




\section{INTERNAL DISTRIBUTION}

1. W. D. Arnold

2. P. T. Barton

3. J. M. Begovich

4. J. T. Bell

5. C. E. Benson

6. W. D. Bond

7. M. D. Boring

8. S. E. Breeding

9. C. H. Brown

10. R. M. Canon

11. D. A. Conatser

12. A. G. Croff

13-22. J. S. Davidson

23. D. L. Daugherty

24. S. M. DePaoli

25. C. A. Easterday

26. J. R. Forgy, Jr.

27-31. V. L. Fowler

32. C. E. Frye

33. W. Fulkerson

34. H. R. Gaddis

35. R. K. Genung

36. R. W. Glass

37. J. D. Hewitt

38. J. H. Hooyman

39. R. J. Hydzik

40. L. L. Jacobs

41. C. M. Kendrick

42. T. E. Kent

43. J. L. Maddox
44. C. P. Manrod

45. R. C. Mason

46. L. E. McNeese

47. D. R. McTaggart

48. S. R. Michaud

49. J. R. Parrott, Jr.

50. B. D. Patton

51-55. J. J. Perona

56. D. J. Peterson

57. W. R. Reed

58. S. M. Robinson

59. S. T. Rudell

60. T. F. Scanlan

61. C. B. Scott

62. R. B. Shelton

63. R. C. Stewart

64. L. E. Stratton

65. P. A. Taylor

66. W. T. Thompson

67. J. R. Trabalka

68. M. W. Tull

69. D. W. Turner

70. J. F. Walker

71. J. H. Wilson

72. E. L. Youngblood

73. Central Research Library

74. Document Reference Section

75-76. Laboratory Records

77. Laboratory Records, R.C.

78. ORNL Patent Section

\section{EXTERNAL DISTRIBUTION}

79-81. T. S. Baer, PAI Corporation, 116 Milan Way, Oak Ridge, TN 37830

82. W. N. Lingle, DOE-ORO, P.O. Box 2001, Oak Ridge, TN 37831-8621.

83. Mac Roddy, DOE-ORO, P.O. Box 2001, Oak Ridge, TN 37831-8621.

84. Doug Underwood, DOE-ORO, P.O. Box 2001, Oak Ridge, TN 37831-8621.

85-87. R. C. Williamson, LICON, Inc., 200 East Government St., Pensacola, FL 32501

88-89. Office of Assistant Manager and Energy Research, DOE-ORO, P.O. Box 2001, Oak Ridge, TN 37831-8600.

90-92. Office of Scientific and Technical Information, DOE.ORO, P.O. Box 62, Oak Ridge, TN 37831. 

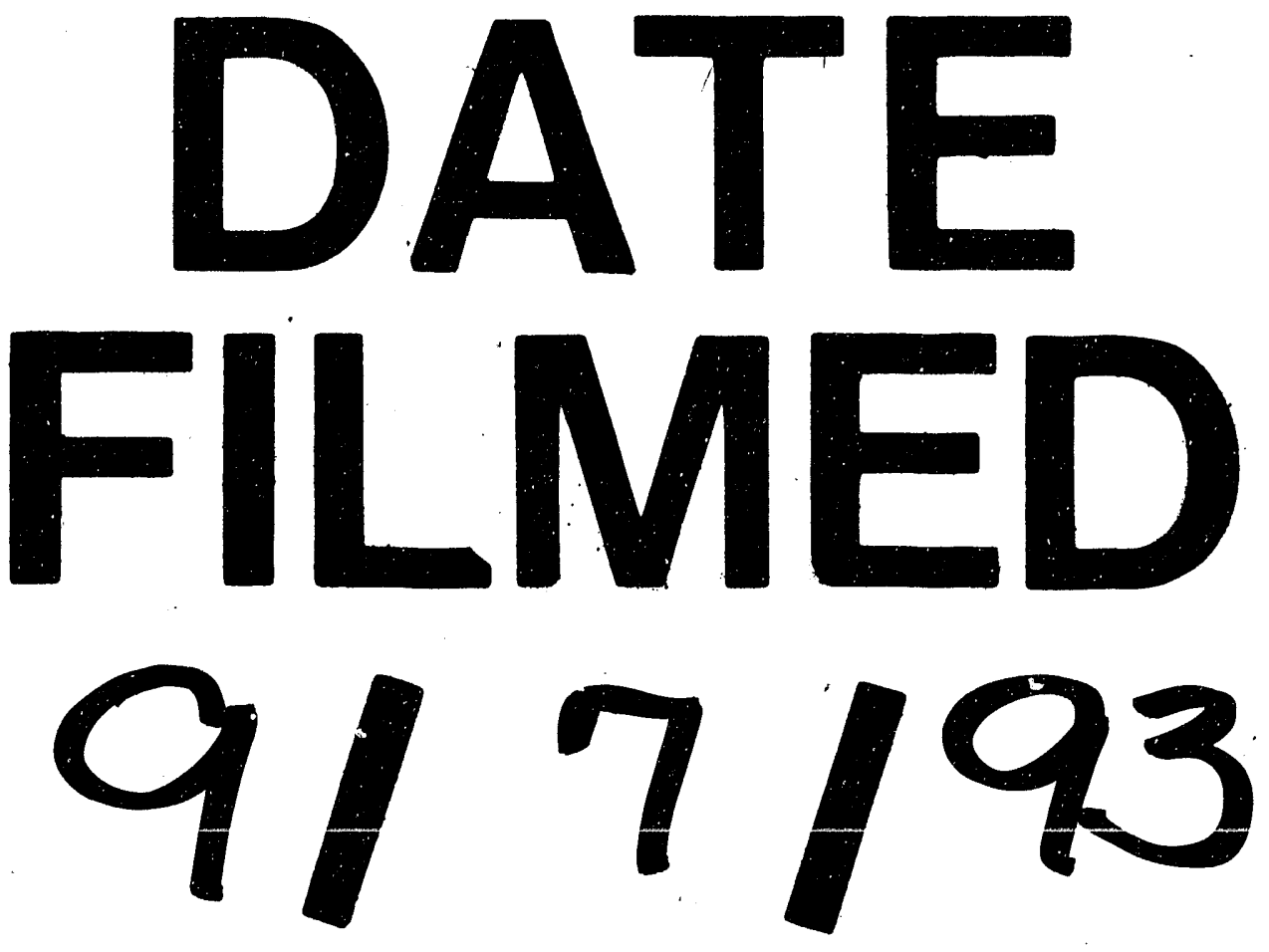
